
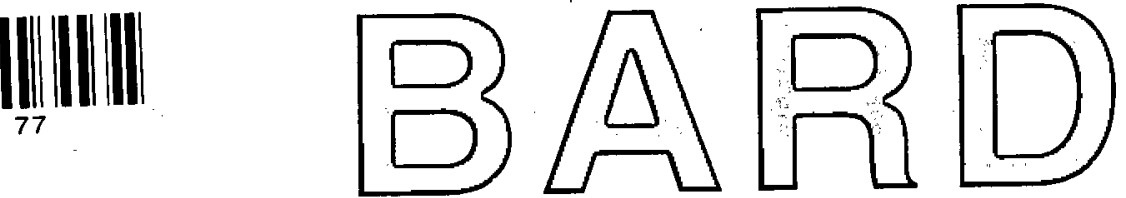

5

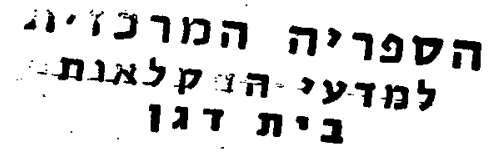

FINAL REPORT

PROJECT NO. IS-1669-89

Biochemical and Physiological Index for Stock and Scion Growth Relationships in Citrus

O. Sagee, C.J. Lovatt 


\section{$43628 \sigma$}

Standard BARD Cover Page for Scientific Reports

Date: $\underline{01 / 03 / 95}$

BARD

P.O. Box 6

הספריה המרכוית הותית

למדעי החקיה המאות

בית דת דת

Bet Dagan, Israel

BARD Project No. $\underline{\text { IS-1669-89R }}$

Title: Biochemical and Physiological Index for Stock and Scion Growth Relationships in Citrus

Investigators' Names

(Principal listed first)

Oded Sagee

Carol J. Lovatt

Project's starting date:

Type of Report: 1st Annual

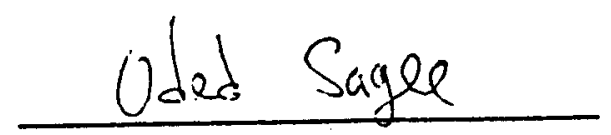

Signature

Principal Investigator
Investigators' Institution

A.R.O The Volcani Center The Regents of the Universitv of California. UCR
$30 / 07 / 1990$

2nd Annual

Final $\mathrm{X}$
Signature

Institutions' Authorizing Official 
Final Report To United States - Israel Agricultural Research and Development Fund (BARD, project I-1669-89)

Biochemical and Phvsiological Index for Stock and Scion Growth Relationships in Citrus

by

O. Sagee and C.J. Lovatt 


$$
\frac{630.72}{B A R / S A G}
$$




\section{Table of contents}

\section{$\underline{\text { Page }}$}

a. Abstract

b. Objectives 2

c. Research activities and results

d. Description of cooperation 17

e. Research achievement 17

f. Benefits to agriculture 18

g. Literature cited 19

h. List of publications originated from the project

\section{Appendixes (manuscripts of relevant papers)}

I. Sagee, O., Atzmon, N. and Shklarman, Y. 1995. Quantitative and qualitative changes in endogenous cytokinins as affected by rootstock type, in citrus.

II. Sagee, O. and Dahan, Y. (1994). Stress and ethylene induced Pathogenesis-Related proteins in citrus.

III. Shklarman, Y., Safran, H. and Sagee, O. (1992). Microscopic study of graft union characteristics and water translocation in young citrus budlings. 


\section{a. Abstract}

Research was undertaken to identify and quantify biochemical and metabolic parameters that are indicative of stionic (scion-rootstock) growth relationships and tree performance, and to quantify the sequence of biochemical and metabolic changes that take place over time at the graft union, in a compatible versus incompatible graft.

Quantitative and qualitative changes in cytokinin levels were found in sprouting buds of 'shamouti' orange, grafted on eleven different rootstocks. Cytokinin levels in roots and shoots were positively correlated to time of bud-break. Rooted cuttings had higher IAA levels than non rooting cuttings.

Transport and metabolism of radiolabeled auxins were different for indole-3-acetic acid than for indole-3 butyric acid. Thus, it is possible that IBA can be transported to the roots also when the graft union is under stress.

Citrus Pathogenesis-Related (PR)-proteins, induced by ethylene and biotic (fungal, viral) or abiotic (calcareous soil, flooding) stress conditions were characterized. Serologically and functionally the proteins were identified as members of the three major classes of PR-proteins, namely, PR-1, chitinase and b-1,3-glucanase.

Rootstocks had a significant effect on the levels of micro- and macroelements in the scion, including sodium and chlorides. Under calcareous soil conditions the rootstock type had major influence on the performance of the grafted tree, particularly when in combination with salinity.

Anatomical and biochemical differences were identified and quantified in the graft-union during early stages of development. As early as six weeks after grafting symptoms of poor graft union and callose build up could be observed in addition to irregularities in water translocation. Accumulation of tannins and catechin was detected along the union zone. Changes in the activity of cathodic isoperoxidase of stem tissue above and bellow the graft union were identified. It is suggested that incompatibility in citrus can be detected and predicted as early as five weeks after grafting using the isoperoxidase assay. The results of this research are being utilized to develop statistically reliable methods for evaluating new rootstocks. 


\section{b. Description of the problem and Objectives of the research}

The performance of a Citrus tree is influenced to a large extent by the rootstock on which it is grafted (Newcomb, 1978; Wutcher, 1979; Castle and Youtsy, 1980; Castle 1982). Although this influence is mainly governed by the interaction between rootstock and the scion, very little is known about the physiological and biochemical mechanisms underlying this phenomenon in Citrus (Mendel 1936, 1969).

Some progress has been made in understanding rootstock involvement in the dwarfing of apples (Lockard and Schneider, 1981). Unfortunately, in Citrus this task is far from being accomplished. The nature of the interrelationship between stock and scion is unknown, as are the mechanisms by which rootstocks influence juvenility, growth, yield and fruit quality. This lack of information is due mainly to the complexity of the problem and to lack of adequate research effort. The pressing needs for additional understanding of the stock-scion (stion) growth relationships and for developing an index for evaluating stionic performance was the underlying motivation for this research.

Our objective was to clarify which biochemical and physiological changes, occuring in the stionic combination, distinguish the performance of a grafted tree from that of each one of its two component parts. This information, dealing with graft union and stion interaction, has a direct implication on the future performance of the tree and is important to the current need of the citrus industry to screen and evaluate new rootstocks (Bitters et al., 1964, 1969; Castle and Youtsey, 1980; Castle, 1982; Roose 1988; Spiegel et al., 1988; Vardi et al., 1988; Shaked et al., 1988).

Therefore, the research objectives were:

(A) Since interrelationship between stock and scion requires communication between the shoot and the root, it is inevitable that signals of yet unknown nature flow through the graft union in both directions. Our working hypothesis was that the amount and/or the nature of the compounds affecting the performance of the grafted tree may vary among Citrus varieties and even cultivars. We proposed that plant hormones, amino acids and protein-systemic signalling may play a role in such a regulating mechanism.

Accordingly, the first objective of the research was:

(A) (i) To establish whether rootstock effect on parameters of stion performance, such as growth vigor, can be correlated to any biochemical and/or metabolic changes, e.g. in the levels and activity of plant hormones, 
amino acids and proteins. We also proposed that following identification of such changes, (ii) we will attempte to manipulate the content or the activity of the compound/s identified and study the growth effect of such manipulation. The second part of this objective was not accomplished because of time limitations.

(B) Using the graft union as a model for studying stock-scion interrelationship, and assuming that it best represents the interface between the two different tissues, our second objective was: (i) To quantify the sequence of biochemical changes that take place during the healing process of the wound in. the scion and rootstock, as new tissues are produced during a successful graft. (ii) To identify and quantify abnormalities in these metabolic events in the wound healing process of a so-called, "incompatible" graft.

(C)The third objective was: To use the factors identified in the first two objectives for singling out rootstocks which have unfavorable effects on stion performance.

\section{c. Research activities and results}

To meet Objective $\mathrm{A}$, the American group conducted research to establish whether rootstock effects on parameters of stion performance, such as growth vigor, can be correlated to any biochemical and/or metabolic differences, e.g., in the level and activity of plant hormones, amino acids, and proteins.

This was done by quantifying endogenous levels of ABA, GA, cytokinins (zeatin, zeatinriboside, isopentyladenine, and isopentyladenosine), and IAA in shoot apices, leaves, root apices, and xylem sap of rootstocks classified as vigorous, of moderate vigor, low vigor, and dwarfing. Quantitation of endogenous plant growth regulators represents a new area of research for Lovatts' lab. A considerable portion of the efforts in meeting Objective $\mathrm{A}$ has been toward developing and standardizing both HPLC and radioimmunoassay techniques for measuring plant grow th regulators.

HPLC - The following conditions for isolation and quantitation of PGRs were established. PGRs were separated on a Zorbax ODS column, $250 \mathrm{x}$ $9.4 \mathrm{~mm}$ equipped with a precolumn. The PGRs were eluted by a gradient solvent system. The initial conditions were $95 \%$ solvent $\mathrm{A}: 0.1 \mathrm{M}$ acetic acid in $10 \%$ aqueous methanol adjusted to $\mathrm{pH} 3.4$ with triethylamine and $5 \%$ solvent B: $100 \%$ methanol. The linear gradient shifts from $5 \%$ solvent 
$\mathrm{B}$ to $50 \%$ solvent $\mathrm{B}$ in $50 \mathrm{~min}$ at a flow rate of $1 \mathrm{ml} / \mathrm{min}$. Retention times for the PGRs were as follows:

$\begin{array}{ll}\text { Zeatin } & 18-19 \mathrm{~min} \\ \text { Zeatinriboside } & 20-21 \mathrm{~min} \\ \text { Indole-3-acetic acid } & 31-32 \mathrm{~min} \\ \text { Gibberellic acid } & 30-32 \mathrm{~min} \\ \text { Abscisic acid } & 42-43 \mathrm{~min} \\ \text { Isopentyladenosine } & 44-45 \mathrm{~min}\end{array}$

To study the metabolism of trytophan to IAA, a method slightly different from that for PGRs, in general, was established. Conditions for HPLC were solvent $\mathrm{A}: 0.1 \mathrm{M}$ acetic acid in $10 \%$ aqueous methanol at $\mathrm{pH}$ 3.5 (instead of ph 3.4) with triethylamine and solvent B: $100 \%$ methanol in a linear gradient from 15 to $50 \%$ B (instead of 5 to $50 \%$ solvent B) in $50 \mathrm{~min}$ at a flow rate of $2 \mathrm{ml} / \mathrm{min}$. Under these conditions, the metabolites eluted with the following retention times:

$\begin{array}{ll}\text { 5-Hydroxytryptamine } & 8.3-8.5 \mathrm{~min} \\ \text { Tryptophan } & 12.4-12.6 \mathrm{~min} \\ \text { Tryptamine } & 13.9-14.2 \mathrm{~min} \\ \text { Indole-3-lactic acid } & 22.3-22.7 \mathrm{~min} \\ \text { Indole-3-aldehyde } & 27.3-27.8 \mathrm{~min} \\ \text { Indole-3-acetic acid } & 29.2-29.7 \mathrm{~min} \\ \text { Indole-3-pyruvic acid } & 34.4-35.2 \mathrm{~min}\end{array}$

RIA - Dr. Lovatt gratefully acknowledges Dr. Jonathan Cutting, University of Natal, for his generosity in supplying all antibodies needed for the RIAs.

Cytokinins - $\left[{ }^{3} \mathrm{H}\right]$ Isopentyladenine, $\left[{ }^{3} \mathrm{H}\right]$ isopentyladenosine, $\left[{ }^{3} \mathrm{H}\right]$ zeatin, and $\left[{ }^{3} \mathrm{H}\right]$ zeatinriboside were made from $[3 \mathrm{H}]$ adenine and $[3 \mathrm{H}]$ adenosine, respectively, by reaction with bromo-methyl-butene and dimethylamine to form, respectively, $\left[{ }^{3} \mathrm{H}\right]$ isopentyladenine and $[3 \mathrm{H}]$ isopentyladenosine. These were reacted with tertiary butylhydroxiperoxide and dichloromethane to yield $\left[{ }^{3} \mathrm{H}\right]$ zeatin and $\left[{ }^{3} \mathrm{H}\right]$ zeatinriboside. $\left[{ }^{3} \mathrm{H}\right] \mathrm{Zeatin}$ and $\left[{ }^{3} \mathrm{H}\right]$ zeatinriboside were isolated from the reaction mixture and purified by HPLC. Recovery of $\left[{ }^{3} \mathrm{H}\right]$ zeatinriboside was in HPLC fractions 19 through 25. $[3 \mathrm{H}]$ Isopentyladenine and $\left[{ }^{3} \mathrm{H}\right]$ isopentyladenosine were purified in a similar manner. 
The antibody to zeatinriboside was tested against its substrate to determine the dilution necessary for $50 \%$ binding (50\% binding is desired to give a range of values over which the standard curve is accurate). Optimal dilution for the antibody to zeatinriboside was found to be $1: 2750$.

Similarly, the optimal dilution of horse serum to be used in the assays was determined. Horse serum provides the extra protein necessary for precipitation for the antibody and the antigen. Optimal conditions are the lowest amount (based on dilution) of horse serum needed in an assay to still maintain $50 \%$ binding. This value was determined for each antibody.

$[3 \mathrm{H}]$ Isopentenyladenosine made from $[3 \mathrm{H}]$ adenosine, as well as $[3 \mathrm{H}]$ isopentenyladenine made from $[3 \mathrm{H}]$ adenine, were purified twice by HPLC. The fractions containing the highest activity were fractions 46 to 58. These fractions were tested for best binding with the antibody. Thereafter, the optimal dilution of the antibody for isopentenyladenosine was established. This antibody can also detect isopentenyladenine. The cross-reactivity was $85 \%$.

GAs - $[3 \mathrm{H}] \mathrm{GA} 3$ was partially purified and provided to us by $\mathrm{Dr}$. Jonathan Cutting. GA3 was further purified by HPLC.

To increase the sensitivity and the stability of the acid PGRs (GAs, ABA, IAA), the tracers, as well as the standards, were methylated. This was done with diazomethane which was produced by reaction of $\mathrm{N}$ nitroso-N-methylurea. Fraction 34 to 37 of the methylated tracer yielded the best binding to the antibody. The optimal dilution of the antibody (50\% binding of tracer) was determined at a dilution of $1: 1000$.

ABA - The tracer was from Amersham; no further purification was requried. Antibody dilution of 1:500 yielded $50 \%$ binding.

IAA - $[3$ H]IAA was purchased from American Radiolabeled Chemicals, no further purification was necessary. The dilution of the antibody for IAA was 1:100. The cross-reactivity of the antibody with tryptophan was tested and found to be less than $1 \%$. Standard curves were set up for all the hormones, the sensitivity of the assays ranks for the following PGRs is:
$\mathrm{Z} / \mathrm{Zr}$
$0.05-20 \mathrm{ng}$
IAA
$0.25-5 \mathrm{ng}$
$\mathrm{GA}_{3}$
$0.025-5 \mathrm{ng}$
$\mathrm{ABA}$
$0.01-10 \mathrm{ng}$
IPA
0.075 - $20 \mathrm{ng}$
IAde (2iP)
$0.1=25 \mathrm{ng}$ (with IPA antibody) 
Hormone Purification - A column system was set up for hormone purification. The system consists of a $5-\mathrm{ml}$ polyvinylpyrolidone column with a 5-ml DEAE ion exchange column below it. Equilibration of the system was done by washing it with $15 \mathrm{ml} 0.01 \mathrm{M}$ ammonium acetate, followed by $15 \mathrm{ml} 1.0 \mathrm{M}$ ammonium acetate. Thereafter, a SepPak cartridge (C18) (preconditioned by flushing with $10 \mathrm{ml}$ methanol) was attached to the DEAE column. These three columns were washed with 15 $\mathrm{ml}$ ammonium acetate before the sample. The supernatant fraction (adjusted to $\mathrm{pH} 7.0$ ) of the original plant sample extracted in $80 \%$ methanol, dried, redissolved in $6 \mathrm{ml} 0.01 \mathrm{M}$ ammonium acetate, and centrifuged at $12,000 \mathrm{~g}$. The system was eluted with $30 \mathrm{ml} 0.01 \mathrm{M}$ ammonium acetate, the SepPak cartridge which contained the cytokinins was removed and saved and the PVP column discarded. Another SepPak cartridge was preconditioned by flushing with $10 \mathrm{ml}$ methanol followed by $10 \mathrm{ml} 0.1 \mathrm{M}$ acetic acid and attached to the sephadex column. This system was eluted with $25 \mathrm{ml} 1.5 \mathrm{M}$ acetic acid and the SepPak containing the acidic hormones removed and saved.

Both SepPak columns were washed with water and eluted with increasing concentrations of methanol in water. The elution of the SepPak columns was done in the following way:

\section{\% Methanol Hormone Eluted}

SepPak I

(cytokinins)

$\begin{array}{ll}10(4 \mathrm{ml}) & \text { discard } \\ 30(4 \mathrm{ml}) & \mathrm{Z}+\mathrm{ZR} \\ 60(4 \mathrm{ml}) & \text { IPA }+2 \mathrm{iP}\end{array}$

SepPak II

(acidic hormones)

$$
\begin{aligned}
& 20(4 \mathrm{ml}) \\
& 60(4 \mathrm{ml})
\end{aligned}
$$

discard

GAs, ABA, IAA

Recovery of the different hormones was tested by running a sample of citrus leaf tissue with a radioactive standard for each hormone. The recovery for reach $P G R$ was as follows:

$\begin{array}{ll}\text { ZR and IPA } & 85 \% \text { recovery } \\ \text { GA3 } & 78-90 \% \text { recovery } \\ \text { IAA } & 40-60 \% \text { recovery } \\ \text { ABA } & 70 \% \text { recovery }\end{array}$

At the time of writing the final report the American group is in the process of analyzing the tissue samples listed above from Rough Lemon vigorous, Troyer Citrange - intermediate vigor, Trifoliate Orange - nonvigorous, and Flying dragon - dwarfing. 
To meet objective A the Israeli group grafted, 'Shamouti' orange (Citrus sinensis L. Osbeck) onto 11 rootstocks which represent most of the available new rootstocks in Israel. The rootstocks were:

Avana mandarin (C. Reticulata); Sun Chu Sha mandarin [SCS]; Sunki mandarin $\mathrm{x}$ Trifoliate orange Beneke [812] (C. sunki $\mathrm{x}$ Poncirus trifoliata); Citrandarin [F805] (C. reticulata $\times$ P. trifoliata); Gou tou (Probably sour orange ( $C$. aurantium) hybrid from China); Citrange [C35] (C. sinensis x P. trifoliata); Rangpur lime $\times$ Swingle Citrumelo [827] (C. reticulata $\mathrm{x}(C$. paradisi $\times$. trifoliata); Rangpur lime $\mathrm{x}$ Troyer citrange [803] (C. reticulata $\times$ ( $C$. sinensis $\times$ P. trifoliata); Cleopatra mandarin $x$ Trifoliate orange [639]; Rusk Citrange (C. sinensis (L.) Osbeck) $\times$ ( $P$. trifoliata (L.) Raf).; Smooth flat Seville [SFS] (Australian sour orange) Probable sour orange hybrid.

Three parameters were studied, as early indicators for rootstock performance. A. vigor, as represented by rate of growth, trunk diameter, branching and vegetative volume. $\mathrm{B}$. Macro $(\mathrm{N}, \mathrm{P}, \mathrm{K})$ and micro $(\mathrm{Fe}, \mathrm{Mn}$, $\mathrm{Zn}, \mathrm{Cu}, \mathrm{Na}, \mathrm{Mo}, \mathrm{B}, \mathrm{Al}$ ) elements and nitrates contents in the leaves. $\mathrm{C}$. Hormonal economy of the grafted tree and changes in the nature and levels of plant hormones in the rootstocks and scions.

On the basis of trunk cross-sectional diameter, citrumelo citrange and sour orange developed at a significantly faster rate while the Avana mandarin was the slowest. Initial budbreak was the earliest in the mandarin types. Under calcareous soil conditions severe chlorosis developed in the leaves of the citrange and citrumelo types whereas the Rangpur-Troyer hybrid was the least affected. Relative ranking of growth, budbreak and tolerance to calcareous soils were evaluated in all rootstocks tested (Sagee et al, 1992a; Sagee et al., 1993).

As expected rootstock type can drastically influence concentration of elements in the leaves. Trangpur (803) had the highest $\mathrm{P}$ and $\mathrm{Z}$, while F805 and CT639 had the highest K. SCS mandarin accumulated Na, like his "sister" rootstock cleopatra mandarin (Sagee et al, 1992a).

Endogenous levels of cytokinins were determined in the roots and sprouting buds of 'Shamouti' orange grafted on various rootstocks.

Our results demonstrate that the type of rootstock can influence the levels and nature of cytokinins in sprouting buds of the scion (Sagee et al., 1995). Date of bud-break was influenced by the rootstock type and was positively correlated to the cytokinin levels. Therefore, we suggest that by analyzing cytokinin levels in sprouting buds of young grafted citrus trees it is possible to receive early information on the potential of that stock- 
scion combination with respect to growth and performance. Rootstocks that induced early bud-break: SCS, SFS, C-35 and GT had the highest cytokinin content in their roots. High correlation was found between the levels of cytokinin in the rootstock and in the scion, especially with regard to $Z$ and ZR (Sagee et al., 1995).

To study the role of auxins in rootstock physiology, two-year-old trees of 'Rangpur' lime (Citrus limonia Osb.) and of 'Oroblanco', a triploid pummelo-grapefruit hybrid (C. grandis Osb. x C.paradisi Macf.), which had not reached flowering stage, were grown under greenhouse conditions (Sagee et al, 1992b). Cuttings from the last vigorous vegetative flush were taken from each species for rooting experiments. Callus formation and percentage of rooting were determined after 19 and 36 days. Endogenous indole-3-acetic acid (IAA) content was determined in leaves and bark (cortex) of the lower end of the cuttings at day of excision and 19 days later. Rooting of the easy-to-root 'Rangpur' lime reached $77 \%$ after 19 days and $100 \%$ after 36 days. At those times the difficult-to-root 'Oroblanco' did not root at all or reached $12 \%$ rooting, respectively. At day 19 the level of free IAA in the bark of 'Rangpur' lime was 3.5 times higher than that at day 0 , and 3.6 times higher than in the 'Oroblanco' bark at the same day. The differences in IAA levels in the two citrus cultivars appear to be correlated with their ease of rooting.

Transport and metabolism of auxins was further studied using radiolabeled indole-3-butyric acid (IBA) and IAA (Epstein and Sagee, 1992). Midrib sections of Cleopatra mandarin (Citrus reticulata B.) were used as a model. IBA transport capacity in the leaf midribs was ca. two times greater in the basipetal direction than the acropetal. The basipetal transport capacity of $3 \mathrm{H}-\mathrm{IBA}$ was lower than that of $14 \mathrm{C}$-IAA (ca. $24 \%$ and $39 \%$, respectively). Most of the radioactivity remained as free IBA. While ethylene treatment reduced basipetal transport of IAA by ca. $70 \%$ it did not affect the transport of IBA.

Exogenous IBA was metabolized by the midribs to a polar compound, probably an ester conjugate. Ethylene pretreatment of the midribs reduced their capacity to metabolize IBA by ca. $70 \%$ as compared to air pretreatment (Epstein and Sagee, 1992). The data indicates that IBA can be transported to the roots even when the graft union is exposed to higher levels of ethylene, as a result of stress. 
To meet Objective B, The American group tested changes in isozymes that were considered as potential predictors of "compatible" versus "incompatible" stion combinations.

Using starch gel electrophoresis, changes in isozyme quantity and/or activity of key enzymes in pathways related to wound-healing response of citrus were quantified by the use of a model system (Lovatt, 1993). The enzymes included: shikimic acid dehydrogenase, peroxidase and acid phosphatase. Isozyme amount and/or activity was quantified: (i) per mg stem tissue from intact seedlings of Troyer Citrange, Calamondin, Kumquat, Valencia, Sweet Orange and Sour Orange, which served as ungrafted, unwounded controls; (ii) per mg graft union tissue from autografts of Troyer Citrange on Troyer Citrange, Calamondin on Calamondin, and Kumquat on Kumquat, Valencia Sweet Orange on Valencia Sweet Orange, and Sour Orange on Sour Orange, which served as the model system for the compatible combination; and (iii) per mg graft union tissue from heterografts of Calamondin on Troyer Citrange and Kumquat on Troyer Citrange, Valencia Sweet Orange on Calamondin, Calamondin on Valencia, and Calamondin on Sour Orange which are known to be incompatible (Weathers and Calavan, 1959; Olson and Frolich, 1968; Bitters et al., 1977).

Considerable time during the first year of the grant was dedicated to developing the model systems for compatible and incompatible stion combinations and optimizing the quantitative separation and staining of the isozymes of shikimic acid dehydrogenase, peroxidase, and acid phosphatase. This extra effort paid off as the system proved highly reproducible, with the exception of shikimic acid dehydrogenase.

All plant material was grown from seed. After removing the seed coat, the seeds were surface sterilized in a $10 \%$ solution of commercial bleach for $10 \mathrm{~min}$ and then rinsed with sterile distilled $\mathrm{H}_{2} \mathrm{O}$. All subsequent steps were carried out under aseptic conditions using sterile techniques. Seeds were transferred to test tubes containing $25 \mathrm{ml}$ of Murashige-Skoog salts, pH 5.7 (Murashige and Skoog, 1962) plus 1\% agar. The cultures were maintained in the dark at $28^{\circ} \mathrm{C}$.

After 3 weeks, the seedlings were ready for grafting. Each plant was decapitated: the 2- to $2.5-\mathrm{cm}$-long apical shoot was used as the scion, and the stem portion ( 3 to $4 \mathrm{~cm}$ long) was used as the rootstock. A modified tip-graft was made. The grafted plants and intact seedlings (ungrafted, unwounded controls) were transferred to liquid nutrient culture medium 
of modified Murashige and Skoog salts, pH 5.7 (Navarro et al., 1975). The cultures were maintained at $28^{\circ} \mathrm{C}$ during $16 \mathrm{~h}$ of light at 1000 lux and $8 \mathrm{~h}$ of dark. Isozyme analyses of the intact stems of the control plants and the graft unions were initiated 1 wcek after the grafts were made and continued each week for 7 weeks.

Just prior to electrophoresis, a sample of $120 \mathrm{mg}$ fresh weight stem tissues from three plants (i.e., three replicates) for each treatment was collected from above and below the graft union for the scion and rootstock, respectively, or from the same position of the stem of the intact (control) seedlings. The samples were immediately homogenized in distilled $\mathrm{H}_{2} \mathrm{O}$ and centrifuged. An aliquot of $3 \mu \mathrm{l}$ supernatant was absorbed into a paper wick (Whatman No. 3 chromatography paper, $2 \mathrm{~mm} \times 10$ $\mathrm{mm}$ ), and the wick was inserted into a horizontal gel of $10 \%$ Connaught starch (Fisher Scientific). Each week, stem samples for all treatments were run on a single gel. For comparison, samples of leaves ( 6 to $10 \mathrm{mg}$ if

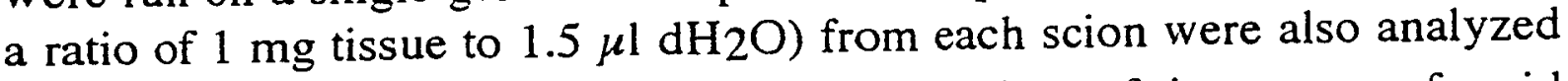
each week on a separate gel. The separation of isozymes of acid phosphatase and peroxidase was by a modification of the tris-citrate-borate buffer system of Poulik (1957). Acid phosphatase was detected by a modification of the method of Scandalios (1969). Peroxidase was detected according to the method of Torres and Bergh (1978). Shikimic acid dehydrogenase isozymes wcre separated using a tris-borate-EDTA buffer system (Gmitter, 1985; Bowman, 1990); and shikimic acid dehydrogenase was detected using the method of Tanksley and Rick (1980) as modified by Bowman (1990).

Results and discussion

Isoenzyme band patterns were determined for seedlings (unwounded controls), autografts (compatible graft combinations), and known incompatible heterografts during the early stages after stem grafting in vitro. Differences in isoenzyme band patterns between seedlings and autografts were interpreted as wound responses and differences in isoenzyme patterns between autografts and incompatible heterografts as incompatible responses.

The incompatible heterografts examined are all well-known and widely accepted incompatible combinations (Weathers and Calavan, 1959; Olson and Frolich, 1968; Bowman, 1991; Williams, 1991). The reported symptoms characterizing the incompatible combinations used in this study resemble those of localized incompatibilities and they are associated not only with the graft union but also with the scaffolding, foliage and roots of 
the trees. The first symptoms, chlorosis and reduction in the number of new flushes, appear several years after grafting and become more noticeable with time. Severely affected trees die but those less severely affected continue to live in a state of reduced vigor. The results described below refer to stem tissue unless leaf tissue is specifically noted.

Shikimic Acid Dehydrogenase - Could not be used as an indicator for predicting incompatibility. First, all the species exhibited a variable number of isoenzymes regardless of whether they were ungrafted or grafted. For this reason, we recorded only the presence or absence of any activity without considering individual isoenzyme bands. Second, even considering only presence or absence of activity, considerable variation was found among the replicates. Third, due to this variation, the results were not reproducible from experiment to experiment. Troyer Citrange, Calamondin and Fortunella autografts did not show any activity at the fifth, sixth and seventh week of the first experiment. However, in the second experiment during the same period, although Troyer Citrange autografts still did not show any activity, Calamondin as well as Sour Orange and Valencia orange appeared to have some degree of activity.

Acid Phosphatase - Both methods for the detection of acid phosphatase gave results which were highly reproducible from experiment 1 to experiment 2 , but not good enough for predicting incompatibility. Method A revealed more bands in comparison to Method B. By Method A, both ungrafted and grafted Fortunella, Calamondin, and Troyer Citrange had a maximum of 8 bands in a similar pattern. Fortunella was distinguished from Troyer Citrange and Calamondin by a larger band at $\mathrm{Rm} 0.35$. In stem of Troyer Citrange seedlings only the bands in the part of the zymogram ranging from $\mathrm{Rm}$ values 0.60 to 0.25 . The results of the first experiment indicated that when grafted, all the species showed changes in the total number of isoenzymes exclusively in the bands located in the part of the zymogram ranging from $\mathrm{Rm}$ values 0.25 to 0.05 .

The percent change in the total number of acid phosphatase isoenzymes of Troyer Citrange, Fortunella, and Calamondin, respectively, in grafted plants compared with seedlings was calculated as follows:

$\%$ change $=\#$ in grafted conditions - \# in seedlings $\times 100$.

\# in seedlings

Wound responses were indicated by the statistically significant changes in the number of bands in stem tissue from autografts compared with seedlings, and incompatible responses by the statistically significant changes in the number of bands in stem tissue from heterografts compared 
with autografts. Although Troyer Citrange showed wound responses from the first to the fifth week, it showed only one incompatible response at week seven with calamondin as the scion. Fortunella showed only one wound response at the third week and one incompatible response at week four. Calamondin appeared to have only very limited wound responses and no incompatible response.

In the second experiment, data were obtained only for Troyer Citrange and Calamondin autografts, and Calamondin on Troyer Citrange heterografts at week seven. The fact that Troyer Citrange and Calamondin appeared to have the same basic banding pattern in the second experiment as in the first experiment and that a statistically significant higher number of isoenzymes was expressed in the Troyer Citrange rootstock of incompatible heterografts compared with the autografts in experiment 2 , indicated the reproducibility of this method of analysis.

However, in conclusion, the number of acid phosphatase isoenzymes revealed with Method A was not a good predictor of incompatibility because differences between compatible and incompatible combinations in either graft partner were observed for only one incompatible combination: Calamondin on Troyer citrange. Analysis of leaf tissue showed no obvious differences in the number of isoenzymes expressed.

For Method B all species had in common two bands. Calamondin was distinguished by the presence of a third band. Calamondin and Fortunella grafted plants, but not seedlings, appeared to have another common band which was not found in leaf tissue of either grafted or ungrafted plants.

ACP isoenzymes detected by Method B were not a useful indicator for predicting incompatibility. This method showed only some minor responses in both wounding and incompatibility, which appeared soon after grafting but did not last long. Fortunella stem tissue from both autografts and heterografts showed an additional band only at the first week after grafting. No difference was found between seedlings and autografts of both Calamondin and Troyer Citrange. The only detected difference between the studied autografts and heterografts was the presence of an additional band in the Calamondin scion of heterografts at the first week after grafting only. The additional band observed for Calamondin as well as the one of Fortunella, was not observed in stem of seedlings, nor in leaves from ungrafted or grafted plants.

Peroxidase - The most significant findings of this research regarding the potential use of isoenzyme analysis to predict incompatibility in citrus were obtained with peroxidase. Both anodic and cathodic isoperoxidases 
were observed for all the species examined and each species could be distinguished by its own banding pattern. Troyer Citrange and Calamondin were used in experiments 1 and 2 and similar results were obtained for both. Thus, the isoenzyme pattern of peroxidase met the two criteria of being able to distinguish species and being reproducible. Leaf and stem tissue of Troyer Citrange, Calamondin and Fortunella, appeared to have the same basic banding patterns with two exceptions: (1) bigger and more intensely stained bands in leaves and (2) absence of band with Rm. +0.31 from leaf tissue of Troyer Citrange.

Experiment 1 - The presence or absence of peroxidase isoenzyme bands, which would be easier to score, was not a good indicator for incompatibility. However, responses to wounding could be scored on the basis of the presence or absence of bands. Troyer Citrange in autografts and in heterografts with Fortunella appeared to have an additional anodic band $(\mathrm{Rm} .+0.31)$ at the first two weeks after grafting which in later weeks disappeared. This band of Troyer Citrange was never found in seedlings, in heterografts with Calamondin, nor in leaves from both seedlings and grafted plants. Although two cathodic bands (Rm. - 0.37 and - 0.44) of Troyer Citrange were constantly expressed in grafted plants, both autografts and heterografts, a variation was observed in seedlings. In seedlings, these bands were always absent at the first two weeks and they were constantly present at the sixth, seventh and the twelfth week. In addition, variation was observed among the replicates at the third, fourth and fifth week. The three bands discussed above were responsible for the observed differences in the total band number of Troyer Citrange among seedlings, autografts and heterografts. The bands of Troyer Citrange with Rm. -0.37 and -0.44 were constantly expressed in leaf tissue.

Calamondin and Fortunella exhibited no differences among seedlings, autografts and heterografts. A very restricted polymorphism was observed for one cathodic band in Calamondin autografts ( $\mathrm{Rm} .-0.16)$ and in Fortunella seedlings (Rm. -0.48). Both bands were rarely absent.

In contrast to scoring the presence or absence of isoperoxidases, activity, in particular the activity of the cathodic isoperoxidases, changed in a manner that was indicative of both wounding and incompatibility. The anodic isoperoxidases did not show any consistent useful variation.

Regarding the wound responses, autografts of all the species examined exhibited increased activity in both scion and rootstock compared with seedlings. Only Calamondin and Fortunella autografts at the sixth and the seventh weeks, respectively, failed to show a change in isoperoxidase 
indicative of wounding. Although in general the rootstock behaved like the scion, a higher activity in the rootstock of Troyer Citrange and Calamondin autografts was found at the third and fourth week.

Regarding the responses to incompatibility detected by the comparison of heterografts with autografts, no significant differences were observed between autografts and heterografts from the first until the fourth week. However, at the fifth and sixth week after grafting both incompatible heterografts showed a decreased activity in their scion and an increased activity in their rootstock. No consistent variation regarding isoperoxidase activity was found in leaf tissue.

The results of the first experiment suggested that the activity of cathodic isoperoxidases of stem tissue above and below the graft union may be an effective predictor for incompatibility, since the revealed incompatible responses were almost identical for both examined incompatible combinations, were different for scion and rootstock, and persisted for two weeks.

Experiment 2 - A second experiment was designed to examine the reproducibility of the experimental system and to determine whether the observed results from the first experiment were unique to Troyer Citrange rootstock or would occur with other incompatible combinations. To achieve these objectives some of the same graft combinations used in the first experiment were used in the second, Troyer citrange and Calamondin autografts and Calamondin on Troyer citrange incompatible heterografts. In addition, Calamondin was grafted on two additional rootstocks, Valencia orange and sour orange, with which Calamondin is incompatible. Since Calamondin and Valencia orange are incompatible regardless of which is the scion and the rootstock, Valencia Orange was grafted on Calamondin in order to examine what occurs in a reciprocal incompatible combination. Stem samples above and below the graft union were examined at the fifth, sixth, and seventh week after grafting, since these weeks were found from the first experiment to be more promising. No difference in the presence or absence of any peroxidase isoenzymes was found between autografts and heterografts. However, the activity of cathodic isoperoxidases followed the same basic pattern as in the first experiment.

At week five after grafting, the Calamondin scion of all the incompatible heterografts showed smaller and less intense cathodic isoperoxidases compared with the scion of Calamondin autografts, identical results to those obtained in the first experiment. However, the 
Valencia Orange scion on Calamondin rootstock did not show the expected decrease in activity. Comparison of the rootstock cultivar of heterografts with the rootstock of its autografts showed that Troyer Citrange with Calamondin as the scion had increased activity as observed in the first experiment. Calamondin rootstock with Valencia orange as scion also exhibited the expected increase in peroxidase activity. While Valencia orange and Sour orange rootstocks grafted with Calamondin scions did not show any change in activity by the fifth week, Sour orange showed the expected increased activity one week later, at the sixth week. However, Valencia orange either as scion or rootstock with Calamondin did not show any change in isoperoxidase activity during the 7-week period of the second experiment.

Although Valencia orange in incompatible conditions with Calamondin did not show any change either as scion or rootstock, Calamondin exhibited the expected changes in pattern, showing decreased peroxidase activity as the scion and increased activity as the rootstock; a situation which still makes it possible to forecast incompatibility. Since in the second experiment, plants were analyzed only at the fifth, sixth and seventh week after grafting, it is possible that a change in the activity of peroxidase isoenzymes of Valencia orange occurred earlier or later and thus, were undetected.

This results demonstrated that of the three enzymes examined, only acid phosphatase and peroxidase gave reproducible results. Although both enzymes responded to wounding, only peroxidase changed reproducibly in relation to incompatibility.

Wound responses were related to more isoenzymes for peroxidase and acid phosphatase as well as with a higher activity of cathodic isoperoxidases in autografts, occurring mostly during the first three to four weeks after grafting. The response of Troyer Citrange to wounding was different and more pronounced than in Calamondin and Fortunella. Only Troyer Citrange autografts had additional isoperoxidases. In addition, Troyer Citrange autografts exhibited an increase in the total number of acid phosphatase isoenzymes (Method A) which appeared earlier, was more pronounced, and lasted for a longer period than in Calamondin and Fortunella autografts. That these responses were related to wounding is confirmed by the fact that they were localized at the graft union and were not found in leaf tissue. An increase in acid phosphatase and peroxidase activity and/or in number of isoperoxidases in response to wounding has been reported previously by several workers (Pitt and 
Galpin, 1971; Villiers, 1971; Moore and Walker, 1981a, b, c; Gaspar et al., 1982.).

Based on the our results we suggest that incompatibility in citrus can be detected and predicted as carly as five wceks after in vitro stem grafting by changes in the activity of cathodic isoperoxidases of stem tissue above and below the graft union, and particularly by their decreased and/or increased activity in the scion and rootstock of incompatible heterografts, respectively.

Further research testing other known incompatible combinations is necessary to conclusively prove the applicability of this method. The reliability of the method would be improved by increasing the number of replicates sampled and increasing the frequency and duration of the sampling period. Finally, future research should include the development of electrophoretic methods for analysis of additional enzymes so that incompatibility could be predicted with a given probability based on a numerical scale.

To accomplish the second objective (quantify the biochemical and anatomical changes that take place during the healing process of the graft union) the Israeli group grafted compatible and so-called incompatible combinations using inverted-T grafts. Calamondin ( $C$. reticulata $\mathrm{cv}$. austera $\times$ Fortunella spp.) and Kumquat (Fortunella crassifolia (Swing) or Fortunella hindisi (Champ.) were grafted on Troyer citrange stock ( $C$. sinensis $\mathrm{x} P$. trifoliata) and for control we grafted Troyer on Troyer and Calamondin on Calamondin. In addition, Calamondin was grafted on Sour orange and on Swingle citrumelo.

Grafts at various developmental stages were isolated surgically and immediately fixed. After fixation, the sections (5-10 $\mu \mathrm{m}$ thick) were stained for light microscopy. Longitudinal sections were also obtained with a freezing microtome and prepared for subsequent Scanning Electron Microscopy (SEM) studies. The SEM was also used for electron microprobe evaluation of calcium and potassium in the graft union zone.

Results show that as early as six weeks after grafting symptoms of poor graft union and callus build up can be observed at the graft union in addition to irregularities in water translocation. Accumulation of tannins and catechin was detected along the union zone (Shklarman et al, 1992).

According to objective B(ii), to identify and quantify abnormalities in the metabolic events in the wound healing process, a group of proteins 
known as pathogenesis related (PR) proteins was studied (Dahan and Sagee, 1992; Sagee and Dhan, 1994).

Using the developed methods for extraction, partial purification and identification of three PR proteins: chitinase (Chit), B-1,3-glucanase (Glu) and PR-1, we experimented the kinetics and the regulation of $P R$ production in different Citrus species. Following ethylene treatment, a significant increase of both Glu and Chit activity was detected, after a lag of about 8-10 hours (Dahan and Sagee, 1992; Sagee and Dhan, 1994).

Glu activity was increased 2.5 (pummelo) to 4 -fold (mandarin) and Chit activity was increased 2 -fold (mandarin) to 3.5 -fold (etrog), after $48 \mathrm{~h}$ of preincubation in ethylene. Although most of the increase was of PRproteins localized in the intracellular extract, about $30 \%$ of the ethyleneinduced activity was detected in the extracellular space. Polyclonal antibodies specific for three classes of acidic PR proteins from PAGEpurified extracellular extracts of TMV-infected tobacco leaves were also antigenic to PRs induced by ethylene in the citrus leaves.

\section{d. Description of cooperation}

The principal investigator, Dr. Oded Sagee visited Dr. Lovatts' Lab during the month of August 1991. Throughout the two weeks stay Sagee performed few experiments aimed to acquaint the people in the Lab with the techniques for measuring the incorporation of radiolabelled carbon into cinnamic acid and p-coumaric acid using the cocrystallization method. This method was developed during Sagees' post doctoral stay at Lovatts' lab at 1988. The two investigators discussed the research progress and exchanged ideas for the continuation of the research. The two groups kept constant communication via elctronic mail and otherwise during the three years of the research.

\section{e. Achievements}

Better understanding of the graft union complex is presumably the basis for the understanding of the new "plant" which consists of two differing partners that become one entity. Interaction of cells in the graft union will effect the formation of a "compatibility complex" which is probably the foundation for the "recognition system" between the two participants in the grafting situation.

We believe that in our project we contributed additional knowledge about the sequence of events during the development of a graft union in 
citrus. We have described the anatomical changes and pointed out several parameters that indicate early signals of possible "incompatibility". Practical implications can emerge from this research as well.

We have pointed out some possible mechanisms whereby a citrus rootstock can affects the performance of the entire tree. The role of cytokinins in the mechanism involved in rootstock influence on tree performance has been demonstrated.

From the point of view of the growers, tree performance is the most important expression of stionic combination. The possibility of an early evaluation of new rootstocks for their performance when grafted onto commercial varieties under different ecological conditions, may considerably reduce the extent and time of rootstock field experiments. We did not pretend to suggest that this research will result in a clear, straight forward-solution for early preselection of citrus rootstock. Nevertheless, we feel that this work will have an impact on our understanding regarding how a stionic combination effect tree performance. We strongly believe that establishment of "indicators" for performance in young rootstocks can be of value to future research geared to improvement of performance of adult budded tree.

\section{f. Benefits to agriculture}

1. Better knowledge and information about the performance of new rootstocks, under various field (soils, water) limiting conditions.

2. Practical parameters to evaluate the "compatibility" of new stock-scion combinations.

3. Additional information on the role of cytokinins and auxins in key physiological phenomena such as bud-break and rooting. It can be assumed that the data accumulated in this research will be used for selection of new rootstocks and/or breeding.

4. The rootstocks that were evaluated in this project are now in field trials. In these trials we already implement the knowledge achieved by the current research. 


\section{g. Literature cited}

Bitters, W.P., J.A. Brusca, and D.A. Cole. 1964. The search for new citrus rootstocks. Calif. Citrog. 49:443-448.

Bitters, W.P., D.A. Cole, and C.D. McCarty. 1977. Citrus relatives are not irrelevant as dwarfing stocks or interstocks for citrus. Proc. Int. Soc. Citriculture 2:561-567.

Bowman, K.D. 1990. Unexploited germplasm, natural mutations, and selected in vitro techniques for citrus cultivar improvement. Ph.D. thesis, Univ. of Florida, Gainesville.

Castle, W.S. 1982. Commercial citrus rootstocks in the United States. Fruit Varieties J. 36:74-79.

Castle, W.S. and C.H. Youtsey. 1980. Trends in Florida citrus rootstocks. Citrus Industry 61:10-14.

Dahan, Y. and O. Sagee. 1992. Effect of ethylene on the induction of B-1,3glucanase and chitinase in citrus leaves. Proc. Int. Soc. Citriculture, Acireale, Italy. 1: 383-386.

Gaspar, T., C. Penel, T. Thorpe, and H. Greppin. 1982. Peroxidases 19701980 , p. 1-129. A survey of their biochemical and physiological roles in higher plants. Universite de Geneve-Centre de Botanique.

Epstein, E. and O. Sagee .1992. Effect of ethylene treatment on transport and metabolism of Indole-3-butyric acid in citrus leaf midribs. Plant Growth Regulation 11: 357-362.

Gmitter, F.G., Jr. 1985. Citrus embryogenesis in vitro: initiation, plant regeneration, and phenotypic characteristics. Ph.D. thesis, Univ. of Florida, Gainesville.

Lockard, R.G. and G.W. Schneider. 1981. Stock and scion growth relationships and the dwarfing mechanism in apple. Hort. Rev. 3:315375.

Mendel, K. 1936. The anatomy and histology of the bud-union in citrus. Palestine J. Bot. Hort. Sci. 1:46.

Mendel, K. 1969. New concepts in stionic relations of citrus. Proc. First Int. Citrus Symp. 1:387-390.

Moore, R. and D.B. Walker. 1981a. Studies of vegetative compatibilityincompatibility in higher plants. I. A structural study of an compatible autograft in Sedum telephoides (Crassulaceae). Am. J. Bot. 68:820-830.

Moore, R. and D.B. Walker. 1981b. Studies of vegetative compatibilityincompatibility in higher plants. II. A structural study of an compatible 
autograft in Sedum telephoides (Crassulaceae) and Solanum pennellii (Solanaceae). Am. J. Bot. 68:831-842.

Moore, R. and D.B. Walker. 1981c. Studies of vegetative compatibilityincompatibility in higher plants.III. The involvement of acid phosphatases in the lethal cellular senescence with an incompatible heterograft. Protoplasma 109:317-334.

Murashige, T. and F. Skoog. 1962. A revised medium for rapid growth and bioassays with Tobacco tissue cultures. Physiologia Plantarum 15:473497.

Navaro, L., C.N. Roistacher, and T. Murashige. 1975. Improvement of shoot tip grafting in vitro for virus- free citrus. J. Am. Soc. Hort. Sci. 100:471-479.

Newcomb, D.A. 1978. Selection of rootstocks for salinity and disease resistance. Proc. Int. Soc. Citriculture 117-120.

Olson, E.O and E.F. Frolich. 1968. Bud-union crease of calamondin-a noninfectious disorder, p. 1-47. In: J.F.L. Childs (ed.). Proc. Fourth Intl. Organiz. Citrus Virology Univ. Fla. Press, Gainesville.

Pitt, D. and M. Galpin. 1971. Increase in ribonuclease activity following mechanical damage to leaf and tuber tissues of Solanum tuberosum L. Planta 101:317-332.

Poulik, M.D. 1957. Starch electrophoresis in a discontinuous system of buffers. Nature 180:1477.

Roose, M.L. 1988. Performance of scion varieties on twenty-one rootstocks in the San Joaquin Valley of Calif. after ten years. Int. Citrus Cong. Abst. 27.

Sagee, O., D. Hasdai, M. Hemo and A. Shaked. 1992a. Screenhouse evaluation of new citrus rootstocks for tolerance to adverse soil conditions. Proc. Int. Soc. Citriculture, Acireale, Italy. 1: 299-303.

Sagee, O., M. Raviv ,S. Medina, D. Becker and A. Cosse. 1992 b. Involvement of rooting factors and free IAA in the rootability of citrus species stem cuttings. Scientia Hort. 51: 187-195.

Sagee, O., A. Shaked, D. Hasdai and M. Hamou. 1993. Rapid evaluation of new citrus rootstocks under semi controlled conditions. 5th International Symposium on Orchard and Plantation Systems. Acta Hort. 349: 197-201.

Sagee, O. and Y. Dahan. 1994. Stress and ethylene induced PathogenesisRelated proteins in citrus. Acta Hort. In Press. 
Scandalios, J.G. 1969. Genetic control of multiple molecular forms of enzymes in plants: A review. Bioch. Genet. 3:37-79.

Shaked, A., A. Goell, and M. Hamou. 1988. Screening citrus rootstocks and rootstock-scion combinations for tolerance to calcareous soils. Int. Citrus Cong. Abst. 62.

Shklarman, Y., H. Safran and O. Sagee. 1992. Microscopic study of graft union characteristics and water translocation in young citrus budlings. Proc. Int. Soc. Citriculture, Acireale, Italy. 1: 342-345.

Spiegel-Roy, P., A. Vardi, A. Elhanati, M. Bar-Yosef, and Z. Solel. 1988. Rootstock selections from a poorman orange $\mathrm{x}$ Poncirus trifoliata cross. Int. Citrus Cong. Abst. 152.

Tanksley, S.D. and C.M. Rick. 1980. Isozymic gene linkage map of the tomato: applications in genetics and breeding. Theor. Appl. Genet. 57:161-170.

Torres, A.M. and B.O. Bergh. 1978. Isoenzymes as indicators of outcrossing among 'Pinkerton' seedlings. Calif. Avocado Soc. Yrbk. 62:103-110.

Vardi, A., P. Spiegel-Roy, G. Ben-Hayyim, and Y. Shalhevet. 1988. Response to shamouti orange and minneola tangelo on six rootstocks to salt stress. Int. Citrus Cong. Abst. 60.

Villiers, T.A. 1971. Lysosomal activities of the vacuole in damage and recovering plant cells. Nature New Biol. 233:57-58.

Weathers, L.G. and E.C. Calavan. 1959. A bud union disorder of calamondin trees in California. Intl. Org. Citrus Virol. Proc. 1:179-184.

Wutscher, H.K. 1979. Citrus rootstocks. Hort. Rev. 1:237-269.

\section{h. List of publications originated from the project}

Epstein, E. and Sagee, O. (1992). Effect of ethylene treatment on transport and metabolism of Indole-3-butyric acid in citrus leaf midribs. Plant Growth Regulation 11: 357-362.

Sagee, O., Raviv, M., Medina, S., Becker, D. and Cosse, A. (1992). Involvement of rooting factors and free IAA in the rootability of citrus species stem cuttings. Scientia Hort. 51: 187-195.

Sagee, O., Shaked, A., Hasdai, D. and Hamou, M. (1993).' Rapid evaluation of new citrus rootstocks under semi controlled conditions. 5 th International Symposium on Orchard and Plantation Systems.Acta Hort. 349: 197-201. 
Sagee, O. and Dahan, Y. (1994). Stress and ethylene induced PathogenesisRelated proteins in citrus. Acta Hort. In Press.

Sagee, O., Atzmon, N. and Shklarma, Y. (1995). Quantitative and qualitative changes in endogenous cytokinins in citrus, effect of rootstock type.

\section{Symposia}

Dahan, Y. and Sagee, O. (1992) Effect of ethylene on the induction of B1,3-glucanase and chitinase in citrus leaves. Proc. Int. Soc. Citriculture, Acireale, Italy. 1: 383-386.

Sagee, O., Hasdai, D., Hemo, M. and Shaked, A. (1992). Screenhouse evaluation of new citrus rootstocks for tolerance to adverse soil conditions. Proc. Int. Soc. Citriculture, Acireale, Italy. 1: 299-303.

Shklarman, Y., Safran, H. and Sagee, O. (1992). Microscopic study of graft union characteristics and water translocation in young citrus budlings. Proc. Int. Soc. Citriculture, Acireale, Italy. 1: 342-345.

Abstracts

Dahan, Y. and Sagee, O. (1991). Induction of B-1,3-glucanase and chitinase in citrus leaves, effect of ethylene. 14th International Conference on Plant Growth Substances, Amsterdam. Abs. p. 93.

Dahan, Y. and Sagee, O. (1994). Ethylene induced pathogenesis-related proteins in citrus. Proc. XXIV International Horticultural Congress, Kyoto, Japan. 1: 280.

Sagee, O. (1991). Effect of ethylene on the induction of phatogenesisrelated proteins in citrus. International Workshop on Plant Growth Substances as Stress Modulators. Halle, Germany. Abs. p. 3.

Sagee, O., Shaked, A., Hasdai, D. and Hamou, M. (1993). Rapid evaluation of new citrus rootstocks under semi controlled conditions. Proc. 5th International Symposium on Orchard and Plantation Systems. Tel-Aviv, Israel.

Sagee, O., Hasdai, D., Shklarman, Y. and Dahan, Y. (1994). Early selection of citrus scion-rootstock (stion) combinations and evaluation of new rootstocks. Proc. XXIV International Horticultural Congress, Kyoto, Japan. 1: 43. 
Quantitative and qualitative changes in endogenous cytokinins as affected by rootstock type, in citrus.

\section{Sagee, O., Atzmon, N., and Y. Shklarman.}

\section{Introduction}

Cytokinins are believed to be produced near the root tip during active root growth (Lockard and Schneider, 1981; Skene, 1975; Van staden and Smith, 1978). In apple (Lockard and Schneider, 1981) and citrus (Saidha et al., 1983) it was shown that larger trees on vigorous rootstocks had higher cytokinin levels. Using soybean bioassay Hendry et al. (1982a) demonstrated that in mature 'Valencia' orange ( $C$. sinencis [L.] Osb.) leaves the levels of polar cytokinins were higher than that of nonpolar during the spring. The situation was reversed in early summer, leaf concentration of polar cytokinins increased relative to previous levels in the spring. In other studies, on young trees, the same group demonstrated that buds from nucellar scions appeared to accumulate higher levels of polar cytokinins during dormancy than old line buds (Hendry et al., 1982b). Cytokinin levels were much higher in buds than in new shoots, leaves or roots tissues. So there appears to be a likelihood that cytokinins may be involved in the effect of rootstocks on the performance of the scion. The effect can be on the timing of bud-break, on differences of growth and, later on, might effect yields and fruit quality.

In this paper we report that, in citrus, the type of rootstock can influence the levels and nature of cytokinins in sprouting buds of the scion. Date of bud-break was influenced by the rootstock type and was positively correlated to the cytokinin levels. Therefore, we suggest that by analyzing cytokinin levels in sprouting buds of young grafted citrus trees it is possible to receive early information on the potential of that stock-scion combination with respect to growth and performance.

\section{Materials and methode}

Plant material - Seedlings of eleven citrus rootstocks, ca. one year old, were transferred from a commercial nursery to a screenhouse in July, 1990. After a short acclimation period, the seedlings were transplanted into 10-liter, well drained, plastic containers.

Rootstocks were: Avana mandarin [AV] (C. reticulata Blanco), Sun Chu Sha mandarin [SCS], 812 [SxB 812] (Citrus sunki x Poncirus trifoliata [L.] Raf.), C-35 citrange [C-35] (C. sinensis L. X Trifoliata), 
Rusk citrange, F-805 citrandarin [F-805] (C. reticulata $\times$. trifoliata), 827 [RxS 827] (Rangpur lime [C. reticulata var. austera Swingle] $x$ Swingle citrumelo), 803 [RxT 803] (Rangpur lime x Troyer citrange), 639 citrandarin [CxT 639] (Cleopatra mandarin x $P$. trifoliata), Gou Tou [GT] ( $C$. aurantium hybrid?) and Smooth Flat Seville [SFS] ( $C$. aurantium hybrid?).

At mid January 1991, the trees were cut back to leave a single $70 \mathrm{~cm}$ high stem, ready for grafting. The rootstocks were grafted with nucellar 'Shamouti' orange (C. sinensis L.) in April 1991. Spring growth from both the scion and the rootstock was pruned to a single $V$ shaped canopy, consisting of scion foliage on one side and leaving a branch of the rootstock subtended on the other side. Two blocks of ungrafted rootstocks were set as control.

The trees were drip irrigated, two emitters in every container to give total of 4 liter/h. During the first year irrigation intervals were once a week for about $15 \mathrm{~min}$ and later on they were increased to twice a week, according tree size. Constant measurements of the drainage were performed to prevent possible salt build up.

$\mathrm{N}, \mathrm{P}, \mathrm{K}$ in the ratio of $4-8-2$ at $30 \mathrm{ppm}$ was added in the irrigation water every second week until September, and in the ratio of 9-4-8 at $100 \mathrm{ppm}$ from April. Fe-138 (sequestrene) was applied to all the trees at a rate of $60 \mathrm{mg}$ per plant in the spring. Additional treatments were on a selective basis and were recorded. Microelements fertilization was included annually in the fertilization program.

In the second and third year of the experiment young shoots and newly formed roots were collected starting at the end of March up to mid April, ca. 1-3 weeks after first bud-break.

The plant material was collected in the morning, triplicates were pooled for each rootstock and kept frozen until extraction.

Extraction and partial purification of cytokinins - One-g samples of frozen plant tissue were placed in $5 \mathrm{ml}$ of $80 \%$ methanol containing 100 $\mathrm{mM}$ ammonium acetate, $45 \mu \mathrm{M} / \mathrm{ml}$ butylated hydroxytoluene (BHT), 1.2 $\mu \mathrm{M}$ diethyldithiocarbamic acid (dieca) and $10 \mu \mathrm{M}$ Kinetin (Sigma) as the internal standard. The samples were homogenized (Polytron) for $1 \mathrm{~min}$ in an ice bath and then kept at $4^{\circ} \mathrm{C}$ for $30 \mathrm{~min}$, vigorously mixed, centrifuged at $5000 \mathrm{~g}$ for $10 \mathrm{~min}$ and the supernatant saved. The pellet was resuspended in $5 \mathrm{ml} 100 \mathrm{mM}$ ammonium acetate and centrifuged as above. Both supernatants were pooled, brought to $50 \mathrm{ml}$ with the 
ammonium acetate solution ( $\mathrm{pH}$ 6.5) and the cytokinins were subjected to three open-column liquid chromatography steps of PVPP, DEAESephadex and C-18.

The cytokinins that passed through the PVPP and DEAE-Sephadex columns adsorb to the C-18 column and were eluted with methanol. Samples were then taken to near dryness, capped and stored at $-70^{\circ} \mathrm{C}$.

The partially purified extracts were additionally purified by reverse phase HPLC [Varian 5500 system equipped with a Lichrosorb RP-18 column $(250 \times 4,7 \mu \mathrm{m})]$. The column was equilibrated with acetic acid TEA (triethylamine) buffer ( $40 \mathrm{mM}$ glacial acetic acid brought to $\mathrm{pH} 3.5$ with TEA) and $10 \%$ acetonitrile. Elution was performed with increased concentration of acetonitrile upto $15 \%$ over $15 \mathrm{~min}$, then to $35 \%$ over 15 min and finally to $100 \%$ over $1 \mathrm{~min}$. The column was recycled to $10 \%$ acetonitrile, and after 20 min equilibration re-injected with new sample. Flow rate was $1 \mathrm{ml} / \mathrm{min}$ and absorbance was detected at $254 \mathrm{~nm}$.

Fraction of $1 \mathrm{ml}$ were collected in eppendorf vials, taken to near dryness and stored at $-70^{\circ} \mathrm{C}$ for quantitative measurements. Cytokinin analysis - Levels of the different cytokinins were determined in each $1 \mathrm{ml}$ fraction using bioassay and/or ELISA (enzyme-linked immunosorbent assay), (Cahill et al., 1986). Confirmation of identity was performed by mass spectrometry as described earlier (Hakomori, 1964; Morris, 1977; Palni et al., 1983).

Bioassay, using soybean callus, was according to Miller (1965) and Van Staden (1991) with modifications. Briefly, the samples were dissolved in $5 \mathrm{ml}$ of basal medium (Miller, 1965), without agar, and placed in $25 \mathrm{ml}$ earlenmyer plugged with steristoppers. The $\mathrm{pH}$ was adjusted to 5.8 with $\mathrm{HCl}$ and additional $5 \mathrm{ml}$ of medium, containing sufficient agar for $10 \mathrm{ml}$, was added before sterilization. Sterilization was achieved by autoclaving. After cooling each Erlenmeyer was planted with four pieces of the stock soybean tissue. The fresh weight averages were measured after 28 days of growth, at $27^{\circ} \mathrm{C}$. Cytokinin contents were calculated by comparison to growth on medium containing cytokinin standards. For quantification of cytokinins via ELISA, each fraction was prepared by adding $22.5 \mu \mathrm{l}$ of DMSO and $22.5 \mu \mathrm{l}$ of PBS-Tween. Coating of the plates (NUNC) was with ZR-ovalbumin $(0.25 \mu \mathrm{g} / \mathrm{ml}, 150$ $\mu \mathrm{l}$ to each well). Blocking with $1 \%$ ovalbumin in PBS-tween. Unknown samples, or standards and Anti-tZR IgG (in proper dilution) were added to the wells. After washing, $200 \mu \mathrm{l}$ of rabbit anti-mouse antibodies- 
Alkaline phosphatase (diluted 1:800 in PBS-tween) were used to quantify the bound-antibody, in each well. Surface-bound alkaline phosphatase activity was determined at $405 \mathrm{~nm}$ after adding $200 \mu \mathrm{l}$ of freshlyprepared p-nitrophenylphosphate $(1 \mathrm{mg} / \mathrm{ml})$. The same method was used with various antibodies (mono and poly clonal). Cytokinin quantity was calculated by comparing the absorbance of the unknown samples to that of standards, using logit transformation. All measurements, for a given extract, were carried out in triplicates. Statistical calculations were made with a statistical package (Soft Max 881, by Molecular Devices) adjusted to ELISA on macintosh computer.

Mass spectra of the permethyl derivatives of zeatin and zeatin riboside were obtained on a Hewlett-Packard 5992a GC-MS using the method of Morris (1977).

Experimental design and statistical analysis - The experiment was organized in a complete randomized block design. The four soil treatments were replicated 5 times and in each plot the 11 rootstocks, in triplicates, were randomly placed. Analysis of variance was used to determine significant difference (SAS) and Duncan's multiple range test was employed for mean comparison at $\mathrm{P}<0.05$.

\section{Results and Discussion}

The first recognizable new bud-breaks were recorded for each tree. The number of elapsed days from initial bud-break of the first rootstock, up to the budbreak of each of the other rootstocks was calculated and defined as time of rootstock bud-break. The rootstock that induced the earliest bud-break was SCS mandarin (Fig. 1).

Five days later bud-break could be recognized on trees grafted on SFS, C-35, GT and AV mandarin. The rest of the rootstocks were much alike and induce bud-break about 20 days later.

Cytokinin-like activity was determined in the shoots, at time of budbreak, using the soybean callus bioassay. For validation, the assay was performed with five different cytokinin standards. On a molar bases, the growth rate on $Z$ was the highest followed by $t-Z R, c, t-Z R$ and IPA (Fig. 2). Kinetin was not effective in concentrations lower than $10 \mu \mathrm{g} / \mathrm{L}$ but very effective in higher concentrations. Zeatin was toxic in concentrations of $50 \mu \mathrm{g} / \mathrm{L}$ and higher (data not shown). To confirm the presence of $Z$ and $Z R$, appropriate HPLC fractions were permethylated and examined by MS. Permethylation of $Z$ fractions at elution volumes 8- 
$9 \mathrm{ml}$ gave derivatives whose mass spectral properties were identical to those of authentic permethylzeatin (Morris, 1977).

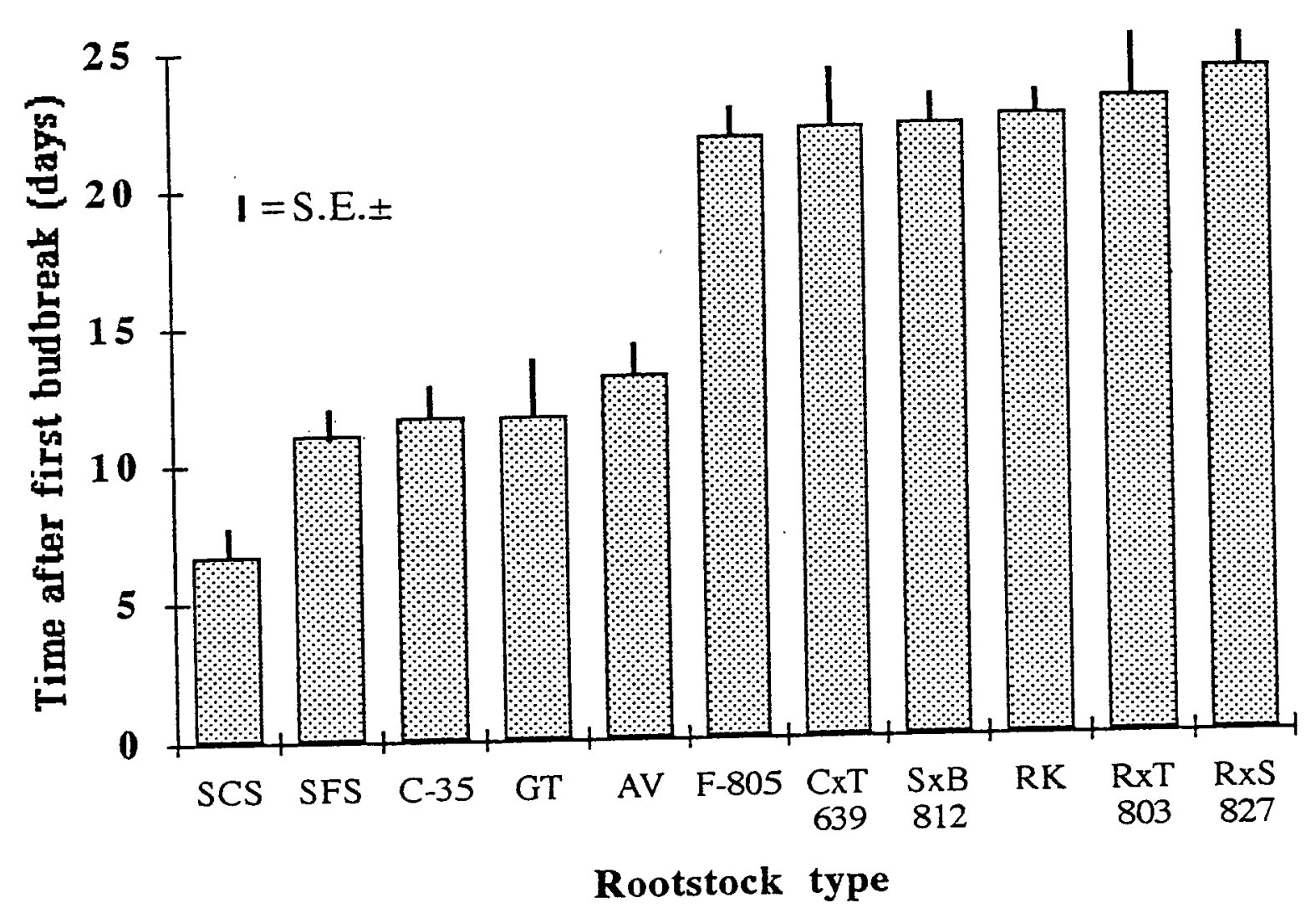

Figure 1: Effect of rootstock type on time of bud-break of 'shamouti' orange. The data shows the number of days that past after the first tree in the shedhouse reached bud-break. Data represents average of 15 trees, \pm S.E.

The molecular ion at $\mathrm{m} / \mathrm{z}=261$ and the fragments at $\mathrm{m} / \mathrm{z}=134,162$, $164,174,199,216,260$, were all present at the expected intentions. ZR was eluted at volumes $11-12 \mathrm{ml}$. and its permethyl derivative showed molecular ion at $\mathrm{m} / \mathrm{z}=421$ with fragments at $390,348,246,230,216$ and 174.

One to two weeks after initial bud-break, the cytokinin levels were determined in the new flush of the 'shamouti' orange scion. When grafted on AV, 812, 827 and 639 rootstocks, endogenous cytokinin levels were low, with more ribosides forms cytokinins being present (Table 1). However, when grafted on GT, C-35, SCS and SFS rootstocks, endogenous cytokinin levels were high and most of them were in "free" forms (Table 1). 


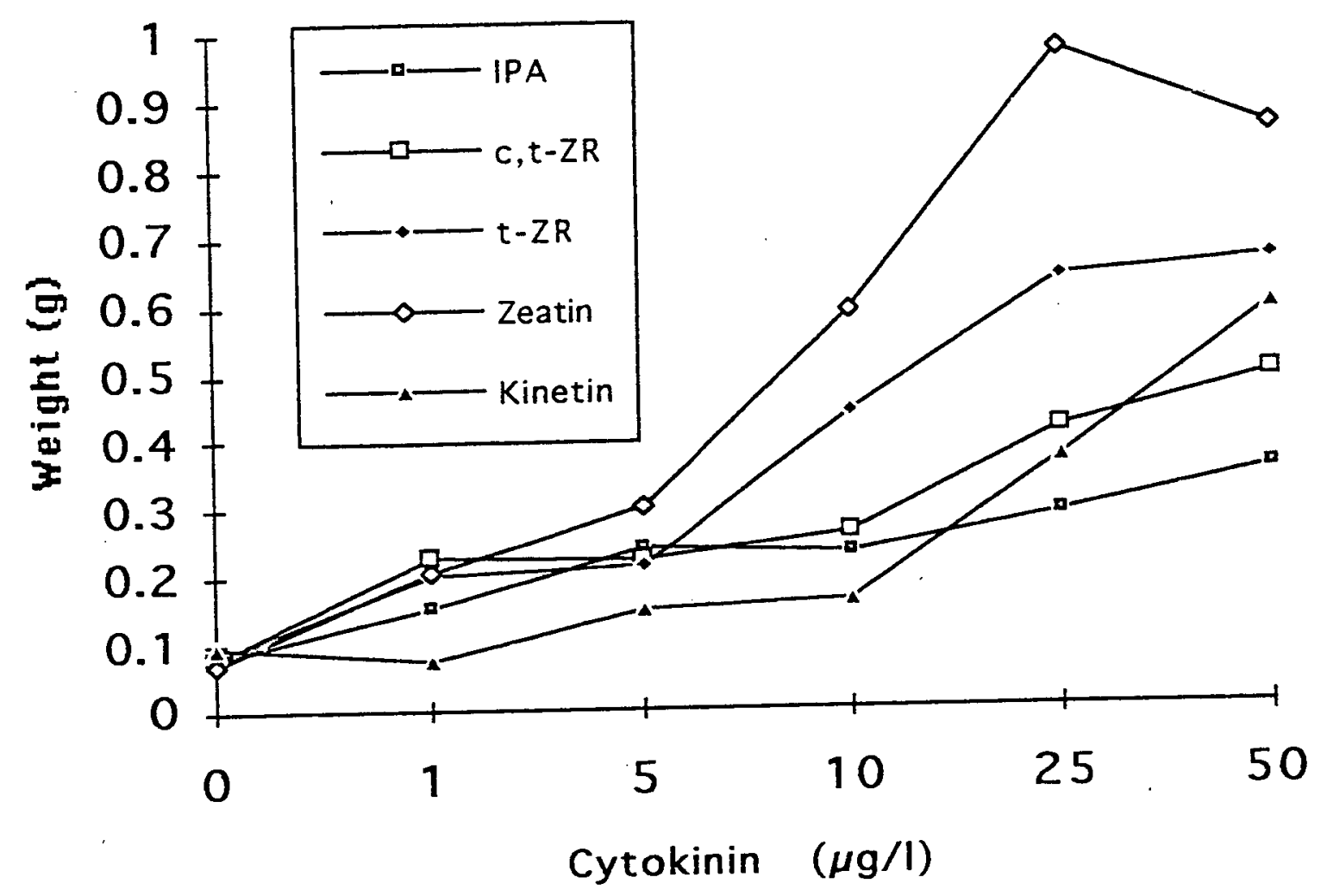

Figure 2: Soybean callus bioassay of different cytokinin standards. IPA=isopentenyl adenosine; $Z=z e a t i n ; Z R=z e a t i n$ riboside.

Rootstocks that induced early bud-break: SCS, SFS, C-35 and GT had the highest cytokinin content in their roots (Table 2). High correlation was found between the levels of cytokinin in the rootstock and in the scion, especially with regard to $Z$ and $Z R$.

The differences observed in cytokinins were both quantitative and qualitative. When grafted on SCS, C-35, SFS and GT rootstocks the major peaks of activity that were detected cochromatographed with $Z$, $Z R$ and IP (Table 1). When grafted on AV, 639 and 812 rootstocks activity co-eluting with $Z$ and $Z R$ was largely absent (Table 1). Activity of fractions co-eluting with DHZR was founfd in appreciable levels only on 812 and RK rootstocks. Significant levels of IPA like activity were detected at elution volumes 28 and 29 when grafted on SCS, C-35 and GT rootstocks. Riboside derivatives of cytokinins ( $Z R, D H Z R$, IPA), in contrast to free bases ( $Z$, iP) were cnosidered a non active forms or "storage" compounds (Letham and Palni, 1983; Parker and Letham, 1973; Stewart and Barthe, 1984). Recently it is beleived that they might 
have a rol as active cytokinins (Kaminek et. al, 1992). The importance of isopentenyl derivatives with respect to growth vigor is not fully understood.

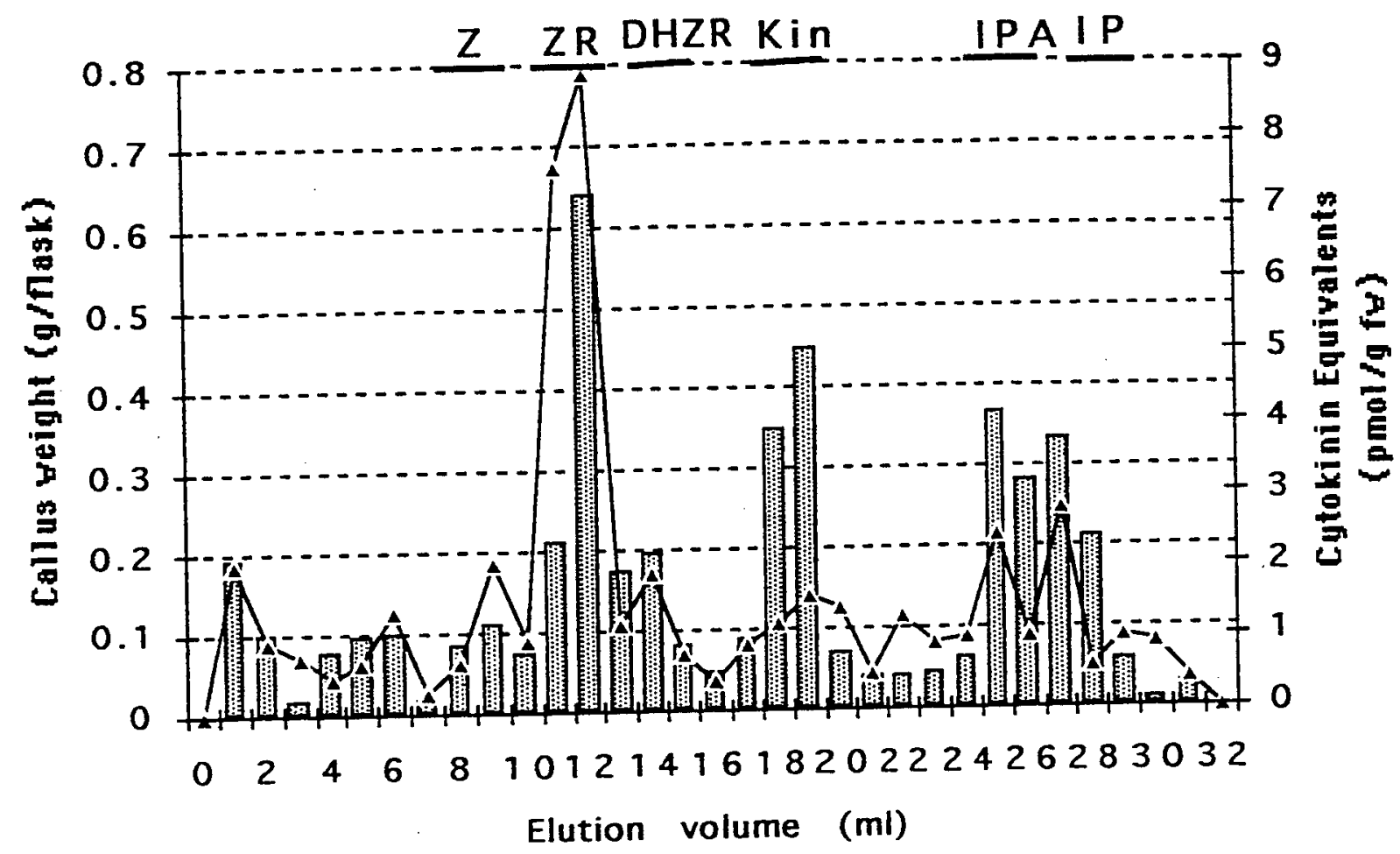

Figure 3. ELISA and soybean callus bioassay of the activity of cytokinins in shoots of 'shamouti' orange, one week after bud-break. The tissue extracts were partially purified and fractionated on Lichrosorb C-18 column.

ELISA (\$), bioassay (퓨).

We can only speculate that the endogenous cytokinin levels in the scion grafted on SCS, C-35 and SFS rootstocks were due to increased transport from the rootstock roots. Other possibilitis, like increased local biosynthesis, decreased degradation or metabolism, effect on sink sorce distributin or alteration of biosynthetic pathways, are certainly valid as well.

In previous studies with orange trees it was demonstrated that when grafted on vigorous rootstock like 'Volkamer' lemon the scion had higher cytokinin levels in the branch sap than those on the less vigorous 'Troyer' rootstock (Saidha et al., 1983). We confirm these findings in our work, and generalize the correlation between cytokinin levels and vigor to more rootstock combinations. In addition we show that concomitantly with bud-break increase cytokinin-like activity can be found in the roots and 
the new flushing, immedeatly after bud-break. It should be noted that we analyzed sprouting buds and not tracheal sap. The minimum injury and short collection period reduced any error due to wound response, which may musk the changes in endogenous cytokinins.

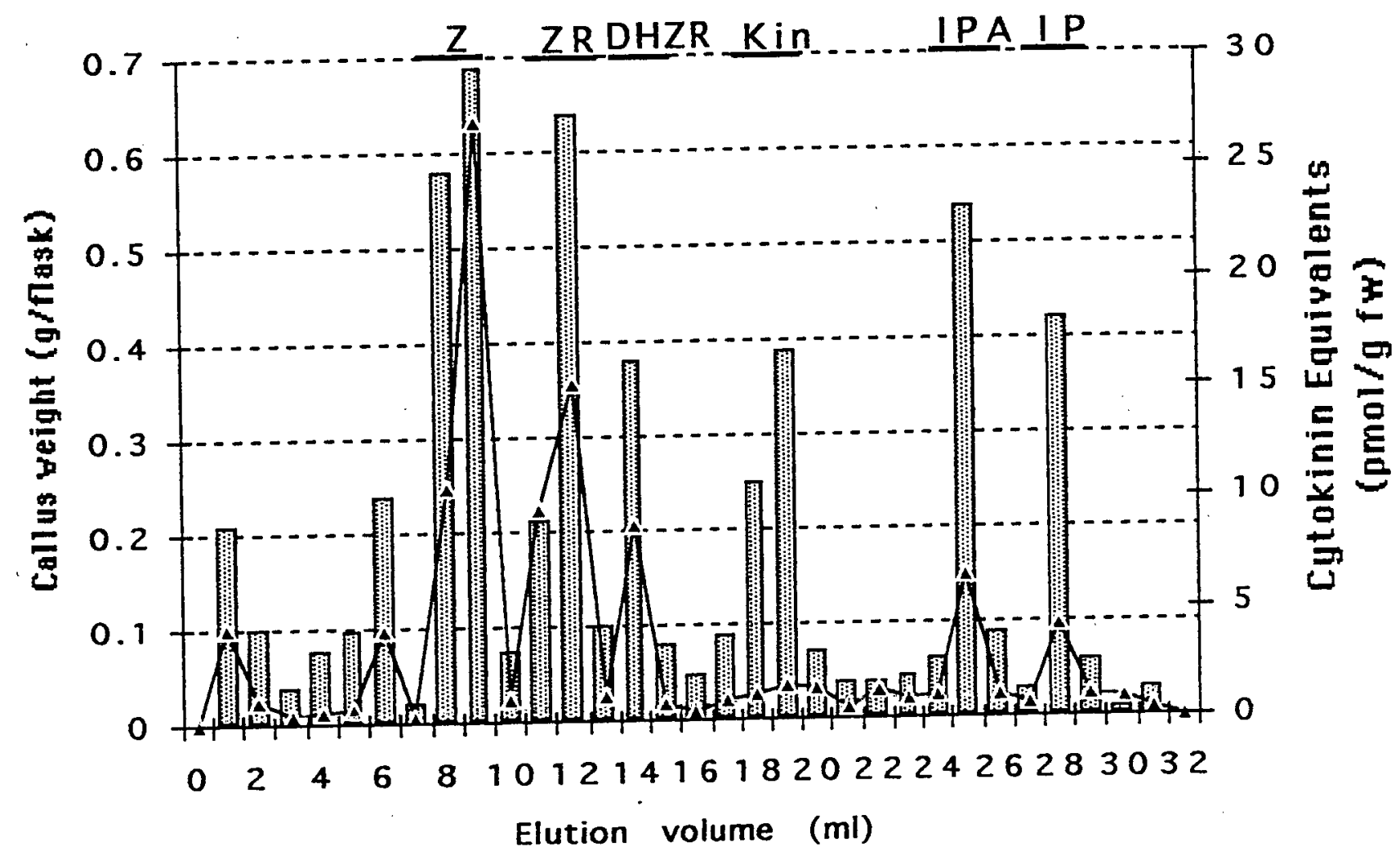

Figure 4. ELISA and soybean callus bioassay of the activity of cytokinins in young roots of C-35 rootstock, grafted with 'shamouti' orange. Roots were collected at time of bud-break (end of March). The tissue extracts were partially purified and fractionated on Lichrosorb C-18 column. ELISA (A), bioassay (15it).

The common knowledge is that cytokinins are produced in roots and then transported to the top part of the tree (Einset, 1991; Kaminek, 1992; Letham and Palni, 1983). In this study it seems clear that root-derived cytokinins may have been translocated to the buds. Wether these cytokinins induced bud break or responded to the sink created during the bud growth we can not conclude. Nevertheless, we demonstrate clear correlation between cytokinin levels in the roots and time of bud-break, as was also reported in other plants (Kaminek et al., 1992).

Therefore, we suggest that by analyzing cytokinin levels in sprouting buds of young citrus trees it is possible to receive early information on 
the growth and performance potential of a particular grafted combination.

Table 1: Contents of cytokinin-like activity in sprouted buds of 'shamouti' orange, grafted on various rootsocks. Data are the mean of three replicates per rootstock, $\pm S E$.

\begin{tabular}{|l|}
\hline Rootstocks \\
\hline 812 \\
\hline AV \\
\hline F805 \\
\hline GT \\
\hline C-35 \\
\hline 827 \\
\hline 803 \\
\hline 639 \\
\hline SCS \\
\hline RK \\
\hline SFS \\
\hline
\end{tabular}

Cytokinin type

\begin{tabular}{|r|}
\hline $\mathbf{Z}$ \\
\hline $2.1 \pm 0.2$ \\
\hline $1.8 \pm 0.1$ \\
\hline $4.3 \pm 0.5$ \\
\hline $8.9 \pm 0.8$ \\
\hline $11.4 \pm 1.9$ \\
\hline $2.2 \pm 0.4$ \\
\hline $4.4 \pm 0.6$ \\
\hline $1.1 \pm 0.1$ \\
\hline $21.5 \pm 4.8$ \\
\hline $5.1 \pm 2.4$ \\
\hline $18.2 \pm 5.5$ \\
\hline
\end{tabular}

\begin{tabular}{|l|}
\hline $\mathbf{Z R}$ \\
\hline $1.4 \pm 0.3$ \\
\hline $1.9 \pm 0.2$ \\
\hline $7.1 \pm 0.5$ \\
\hline $6.8 \pm 0.3$ \\
\hline $5.7 \pm 1.0$ \\
\hline $4.4 \pm 0.5$ \\
\hline $6.1 \pm 0.9$ \\
\hline $2.0 \pm 0.2$ \\
\hline $8.5 \pm 2.1$ \\
\hline $1.9 \pm 0.5$ \\
\hline $5.5 \pm 2.7$ \\
\hline
\end{tabular}

\begin{tabular}{|c|}
\hline DHZR \\
\hline $8.2 \pm 1.4$ \\
\hline $5.6 \pm 0.3$ \\
\hline $4.5 \pm 0.4$ \\
\hline $2.2 \pm 0.2$ \\
\hline $3.6 \pm 0.2$ \\
\hline $4.4 \pm 0.6$ \\
\hline $1.1 \pm 0.1$ \\
\hline $3.2 \pm 0.6$ \\
\hline $4.1 \pm 1.2$ \\
\hline $8.7 \pm 3.1$ \\
\hline $3.3 \pm 1.9$ \\
\hline
\end{tabular}

\begin{tabular}{l}
$(\mathrm{pmol} / \mathrm{g} \mathrm{fw})$ \\
\hline IPA \\
\hline $2.4 \pm 0.2$ \\
\hline $4.1 \pm 0.4$ \\
\hline $2.1 \pm 0.1$ \\
\hline $1.1 \pm 0.1$ \\
\hline $3.4 \pm 0.4$ \\
\hline $2.5 \pm 0.6$ \\
\hline $4.4 \pm 0.2$ \\
\hline $1.8 \pm 0.4$ \\
\hline $2.9 \pm 0.7$ \\
\hline $5.1 \pm 2.4$ \\
\hline $1.9 \pm 0.4$ \\
\hline
\end{tabular}

\begin{tabular}{|l|}
\hline IP \\
\hline $1.1 \pm 0.1$ \\
\hline $2.0 \pm 0.2$ \\
\hline $2.4 \pm 0.4$ \\
\hline $5.2 \pm 0.5$ \\
\hline $6.1 \pm 0.7$ \\
\hline $3.9 \pm 0.7$ \\
\hline $4.9 \pm 0.8$ \\
\hline $4.1 \pm 0.9$ \\
\hline $7.8 \pm 3.7$ \\
\hline $0.9 \pm 0.1$ \\
\hline $6.1 \pm 2.4$ \\
\hline
\end{tabular}

Table 2: Cytokinin-like content in young roots of various citrus rootsocks grafted with 'shamouti' orange scion. Data are the mean of three replicates per rootstock, $\pm S E$.

\begin{tabular}{|l|r|r|r|r|r|}
\multicolumn{7}{c|}{ Cytokinin type and quantity } \\
\hline Rootstocks & \multicolumn{1}{|c|}{ Z } & \multicolumn{1}{c|}{ ZR } & \multicolumn{1}{c|}{ DHZR $/ \mathrm{g} \mathrm{fw}$ ) } & \multicolumn{1}{c|}{ IPA } & \multicolumn{1}{c|}{ IP } \\
\hline $\mathbf{8 1 2}$ & $6.4 \pm 0.6$ & $3.0 \pm 0.7$ & $17.1 \pm 3.1$ & $8.0 \pm 2.4$ & $5.0 \pm 0.7$ \\
\hline $\mathbf{A ~ V}$ & $5.9 \pm 0.8$ & $8.1 \pm 1.7$ & $12.1 \pm 1.9$ & $12.1 \pm 3.2$ & $9.0 \pm 2.9$ \\
\hline F 805 & $12.1 \pm 1.9$ & $20.0 \pm 4.5$ & $10.0 \pm 3.0$ & $8.4 \pm 2.3$ & $10.1 \pm 2.6$ \\
\hline GT & $27.5 \pm 3.1$ & $16.1 \pm 2.1$ & $4.0 \pm 0.3$ & $4.0 \pm 0.9$ & $2.5 \pm 0.9$ \\
\hline $\mathbf{C - 3 5}$ & $35.6 \pm 4.0$ & $17.3 \pm 3.3$ & $8.8 \pm 2.7$ & $13.8 \pm 3.6$ & $7.2 \pm 1.9$ \\
\hline $\mathbf{8 2 7}$ & $5.3 \pm 0.7$ & $17.0 \pm 2.0$ & $11.6 \pm 1.1$ & $7.7 \pm 1.9$ & $8.2 \pm 2.7$ \\
\hline $\mathbf{8 0 3}$ & $11.0 \pm 1.9$ & $18.5 \pm 2.4$ & $4.0 \pm 0.9$ & $14.6 \pm 4.2$ & $2.2 \pm 0.5$ \\
\hline $\mathbf{6 3 9}$ & $5.1 \pm 0.9$ & $7.7 \pm 1.0$ & $7.6 \pm 3.0$ & $6.2 \pm 1.0$ & $6.7 \pm 1.6$ \\
\hline SCS & $59.4 \pm 7.0$ & $22.2 \pm 7.6$ & $8.4 \pm 0.7$ & $7.9 \pm 1.1$ & $8.2 \pm 3.0$ \\
\hline RK & $17.1 \pm 2.1$ & $6.9 \pm 0.9$ & $18.9 \pm 2.9$ & $17.9 \pm 3.2$ & $2.9 \pm 0.8$ \\
\hline SFS & $50.0 \pm 8.9$ & $19.0 \pm 2.2$ & $9.1 \pm 1.4$ & $5.1 \pm 0.8$ & $11.6 \pm 4.4$ \\
\hline
\end{tabular}

One may speculate that such information may also indicate about future characteristics of the tree including fruit quality, since cytokinin levels are one of the factors that influence fruit growth and quality (Goren and Monselise, 1976). 


\section{References}

Cahill, D.M., Weste, G.M. and B.R. Grant. 1986. Changes in cytokinin concentrations in xylem extrudate following infection of Eucalyptus marginata Donn ex Sm with Phytophthora cinnamomi Rands. Plant Physiol. 81:1103-1109.

Einset, J.W. 1991. Woody plant micropropagation with cytokinins. In: Biotechnology in Agriculture and Forestry, Vol. 17, High-Tech and micropropagation I, (ed. by Y.P.S., Bajaj). Springer-Verlag, Berlin Heidelberg.

Goren, R. and S.P. Monselise. 1976. The rough fruit condition of the 'Shamouti' orange - conection with the endogenous hormonal balance. J. Hort. Sci. 51:367-374.

Hakomori, S. 1964. A rapid permethylation of glycolipid, and polysaccharide catalyzed by methylsulfinyl carbanion in dimethyl sulfoxide. J. Biochem. 55:205-208.

Hendry, N.S., J. Van Staden and P. Allan. 1982a. Cytokinins in citrus. I Fluctuation in the leaves during seasonal and developmental changes. Scientia Horticulturae 16:9-16.

Hendry, N.S., J. Van Staden and P. Allan. 1982b. Cytokinins in citrus. II. Fluctuation during growth in juvenile and adult plants. Scientia Horticulturae 17:247-256.

Kaminek, M. 1992. Progress in cytokinin research. Tibtech 10:159-164.

Kaminek, M., D.W.S. Mok and E. Zazimalova.1992. Phisiology and Biochemistry of cytokinins in plants. SPB Academic Publishing.

Lockard, R.G. and G.W. Schneider. 1981. Stock and scion growth relationships and the dwarfing mechanism in apple. Hort. Rev. 3:316375.

Letham, D.S. and L.M.S. Palni. 1983. The biosynthesis and metabolism of cytokinins. Annu. Rev. Plant Physiol. 34:163-197.

Miller, C.O. 1965. Evidence for the natural occurrence of zeatin and derivatives: compounds from maize which promote cell division. Proc. Nat. Acad. Sci. 54:1052-1058.

Morris, R.O. 1977. Mass spectroscopic identification of cytokinins, glucosyl zeatin and glucosyl ribosylzeatin from Vinca rosea crown gall. Plant Physiol. 59:1029-1033.

Palni, L.M.S., R.E. Summons and D.S. Letham. 1983. Mass spectrometric analysis of cytokinins in plant tissues. V. Identification of the cytokinin complex of Datura innoxia crown gall tissue. Plant Physiol. 72:858-863.

Parker, C.W. and D.S. Letham. 1973. Mmetabolism of zeatin by radish cotyledons and hypocotyls. Planta 114:199-218.

Saidha, T., E.E. Goldschmidt and S.P. Monselise. 1983. Endogenous growth regulators in tracheal sap of citrus. HortScience 18:231-232. 
Skene,K.G.M. 1975. Cytokinin production by roots as factor in the control of plant growth. In: J.G. Torrey and D.T. Clarkman (Eds), The Development and Function of Roots. Academic Press, London, pp. 375-396.

Stewart, I. and G.A. Barthe. 1984. Cytokinins in citrus. Proc. Int. Soc. Citriculture. 1:289-290.

Takagi, M., T. Yokota, N. Murofushi, H. Saka and N. Takahashi. 1989. Quantitative changes of free-base, riboside, ribotide and glucoside cytokinins in developing rice grains. Plant Growth Reg. 8: 349-364.

Van Staden, J. and A.R. Smmmith. 1978. The synthesis of cytokinins in excised roots of maize and tomato under aseptic conditions. Ann. Bot.42:751-753.

Van Staden, J. and F.E. Drewes. 1992. Metabolism of ribosylzeatini-5'monophosphate by soybean callus. Plant Growth Reg. 11:189-191. 


\section{STRESS AND ETHYLENE INDUCED PATHOGENESIS-RELATED PROTEINS IN CITRUS}

Sagee, O. and Y. Dahan

\section{Introduction}

Exogenously-applied ethylene has been found to enhance or activate a variety of biochemical pathways and physiological functions (Abeles, 1973). It is assumed that this gaseous plant growth regulator is one of the natural mediators of pathogenesis-related (PR) protein accumulation (Boller, 1988; Felix and Meins, 1987; Vogeli et al., 1988), as has been found for other defense functions. The involvement of ethylene in the regulation of b-1,3-glucanase and chitinase activity was initially demonstrated in abscising bean leaves by Abeles et al. (1970) and was later confirmed in many other plants (Boller, 1988). In contrast to the pathogen-induced enzymes which are localized in the extracellular space (Boller and Metraux, 1988; Boller and Vogeli, 1984) the localization of ethylene-induced b-1,3-glucanase and basic isoforms of chitinase was found to be mostly intracellular in bean (Boller and Vogeli, 1984; Mauch and Staehelin, 1989). In tobacco it has recently been established that the acidic and basic isoforms of PRs display different subcellular localization (Lotan and Fluhr, 1990). In citrus, there is no data regarding the role of ethylene in the induction and localization of b-1,3glucanase and chitinase. Thus, we used antibodies specific for PR proteins to examine the presence and activity of these enzymes in Citrus.

The three species, etrog citron ( $C$. medica L.), mandarin orange ( $C$. reticulata Blanco), and pummelo ( $C$. grandis [L.] Osbeck) were selected for the study since they are considered to be the source for all the other many species constituting the Citrus genus, by interspecific crosses (Swingle, 1967).

Mal-secco disease, caused by Phoma tracheiphila, is a serious tracheomycotic fungal disease of Citrus. Lemon (C. limon (L.) Burm) citron ( $C$. medica L.) and sour orange ( $C$. aurantium L.) are most susceptible species and also mandarin ( $C$. reticulata Blanco) when grafted on infected sour orange (Klotz, 1978).

Citrus exocortis viroid (CEV) attacks citrus trees when they are grafted on susceptible rootstocks like Rangpur, Trifoliate orange, and 
some of the trifoliate hybrids, such as Troyer and Carizo citranges and certain citrumelos. The disease was first named "scaly butt" due to the bark scaling symptoms found on infected trees (Wallace, 1978).

Tolerance to flooding is one of the requirements of citrus rootstocks although a thorough understanding of the mechanisms involved in such a tolerance is lacking. Damage to the roots results from various changes of the root zone, such as anaerobic conditions, oxygen deficiency, increase of toxic metabolites and alteration of soil structure ( $\mathrm{Vu}$ and Yelenosky, 1992). Tolerant rootstocks are characterized by the ability to rapidly initiate new roots for replacement of dead roots and resistance to fungus disease caused by Phytophthora parasitica .

Combining of rootstock and a scion (variety) by grafting is the usual practice of citrus propagation. When the union between scion and the stock develops without difficulty it is considered a compatible combination. However this is not always the case, since some citrus species are not graft compatible with each other. Incompatibility can be considered as a stress phenomena associated with graft union disorder and collapse of the vascular system, resulting with tree decline and death.

Since PR proteins are considered a part of the overall battery of defense mechanisms used by plants for protection from, and against, various biotic and abiotic stress conditions we determined the changes in PR-protein levels caused by diverse stress conditions and in various Citrus varieties.

\section{Materials and Methods}

Plant material and stress conditions -One-year-old seedlings of Troyer citrange [C. sinensis (L.) Osb. $x$ Poncirus trifoliata (L.) Raf.] were grown in $15 \mathrm{~L}$ containers and then exposed to flood conditions (FL) by preventing drainage from the container for up to 30 days. After the flooding period leaves and roots were collected for protein extraction. Incompatibility (INC) was studied 8 months after grafting of Calamondin (C. reticulata Aus.? x Fortunella sp.?) on Troyer citrange, the graft area was used for protein extraction. Mal-secco infected tissues from mature lemon ( $C$. limon) trees were collected from commercial groves, frozen and processed for protein extraction. For the Citrus Exocortis Viroid (CEVd) experiments, leaves and roots were collected from two-year-old etrog citron ( $C$. medica L.) trees infected 
with the viroid. For the ethylene experiments, mature leaves from the current year flush were taken from one-to two-year-old seedlings of etrog citron, mandarin orange (C. reticulata Blanco) and pummelo ( $C$. grandis [L.] Osbeck). The leaves were immediately transferred to sealed containers, under humidified conditions, for further treatments.

Treatment with ethylene - Leaves were incubated in air-tight glass chambers and treated with a continuous, humidified, air stream at the rate of $300 \mathrm{ml} \mathrm{min}^{-1}$, with or without ethylene. Air or $10-25 \mathrm{~mL} \mathrm{~L}^{-1}$ ethylene were supplied through a system of flowmeters calibrated for the desired ethylene concentration by gas chromatography. Incubation was carried out in the dark at $25^{\circ} \mathrm{C}$.

Protein extraction and preparation - The plant material was either immediately homogenized, or prepared for extraction of the intercellular wash fluid (IWF). Soluble proteins were extracted from the plant tissue in phosphate-citrate buffer pH 5.0 (sodium phosphate 30 $\mathrm{mM}$, citrate $80 \mathrm{mM}$, ascorbate $5 \mathrm{mM}$, mercapto-ethanol $14 \mathrm{mM}$ ) using a pestle in a mortar containing quartz sand. Batches of $1 \mathrm{~g}$ tissue (fresh weight) were extracted in $4 \mathrm{ml}$ of buffer solution. For large batches, a Waring blender was used. The homogenate was filtered through Miracloth (Calbiochem, Ca, USA), the filtrate then centrifuged at $10,000 \mathrm{~g}$ for $10 \mathrm{~min}$. and the supernatant stored at $4^{\circ} \mathrm{C}$. IWF was prepared from 3-5 $\mathrm{g}$ of plant material that were vacuum-infiltrated with IWF buffer ( $10 \mathrm{mM}$ sodium acetate, $\mathrm{pH} 5.0$ ), dried by blotting on paper towels, and placed in plastic syringes. Eppendorf microcentrifuge tubes $(1.5 \mathrm{ml})$, without caps, were mounted on the tip of the syringes and they were both fitted into plastic centrifuge tubes. The IWF was collected by centrifuging the syringes at $1500 \mathrm{~g}$ for $30 \mathrm{~min}$., and frozen at $-20^{\circ} \mathrm{C}$. Enzymatic activities of IWF and homogenates were compared on the basis of fresh weight and protein content (Bradford, 1976).

Gel electrophoresis and immune blots - Proteins were fractionated in sodium-dodecyl-sulfate (SDS) polyacrylamide-gel electrophoresis (PAGE) as described by Laemmli (1970) using mostly minigels consisting of $10 \%-15 \%$ ( $/ \mathrm{v}$, acrylamide) separating gel overlaid by a $5 \%(w / v)$ stacking gel. Molecular-weight standards were from Pharmacia (Uppsalla, Sweeden). PAGE under native conditions for acidic proteins was in $10 \%$ polyacrylamide slab gels according to Davis (1964). Gels were stained with Coomassie blue G-250 and destained in distilled water. Immunoblots were processed according to Towbin et al., 
(1979) with few modifications. Proteins were transferred electrophoretically to nitrocellulose membranes (Biotrace NT, $0.45 \mu$, Gelman Sciences, USA) and, for blocking the membranes, were incubated for $1-2 \mathrm{~h}$ at room temperature with $2 \%$ skimmed milk in phosphate-buffered saline (PBS). Diluted antiserum prepared by injecting rabbit with protein bands corresponding to chitinase and B-1,3glucanase, from IWF of TMV-infected tobacco leaves (Lotan et al., 1989) was added for a 2 -h incubation, and the nitrocellulose was rinsed thoroughly with PBS containing $50 \mathrm{mM}$ EDTA and $1 \%$ Triton X-100. The blots were stained for peroxidase by the method of Avrameas and Guilbert (1971) or by using the enhanced chemiluminescence (ECL) western blotting (Amersham, UK). For quantitative measurements hybridization signals were analyzed from autoradiographs using personal densitometer (Molecular Dynamics, USA) analytical imaging instrument, equipped with digital image and data processing unit and integrating software.

\section{Results}

Effect of ethylene on changes in prolein profile -Treatment with 15 $\mu \mathrm{L} \mathrm{L}-1$ of ethylene for $48 \mathrm{~h}$ resulted in notable changes in protein profiles in all the three citrus species examined (Fig. 1). Comparison of SDS-page analysis of ethylene-treated pumello (Fig. 1P), mandarin (Fig. $1 \mathrm{M}$ ) and etrog (Fig. 1E) shows that following the ethylene treatment at least four proteins (arrows) were induced in each species, as compared to controls where ethylene was not supplied. Three bands with an apparent molecular mass of $11-12 \mathrm{kD}, 14 \mathrm{kD}$ and $19 \mathrm{kD}$ appeared in all the ethylene treated leaves. In the ethylene treated Etrog leaves two additional bands at $17 \mathrm{kD}$ and $23 \mathrm{kD}$ (arrows) were present.

Partial identification of $P R$ proteins in ethylene treated mandarin leaves - The use of anti-PR protein antibodies developed against PR2,N,O; PR-P,Q and PR-1a,1b,1c from TMV-infected tobacco (Lotan and Fluhr, 1990) allowed the detection among the ethylene-induced mandarin proteins of some proteins that were serologically related to tobacco PR proteins (Fig. 2).

The three classes of tobacco TMV-induced-PR-proteins examined, had counterparts induced by ethylene in citrus mandarin, namely, $\beta-1,3-$ glucanase, chitinase and PR-1-like proteins (Fig. 2). 


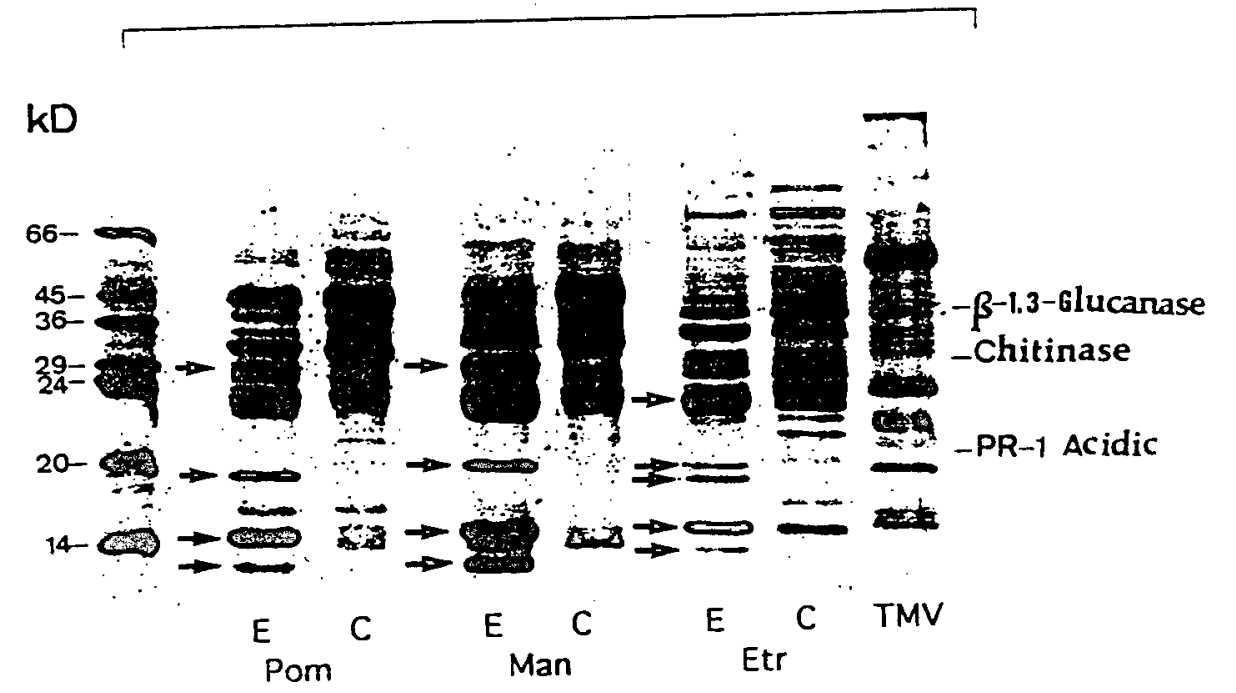

Fig. 1. Ethylene effect on changes of protein patterns in leaves from various Citrus species. Leaves were treated for $48 \mathrm{~h}$ with air ( $C$, control) or with air supplemented with $15 \mu \mathrm{L} \mathrm{L}^{-1}$ ethylene (E). Extracellular proteins were separated on SDS-PAGE using 5-15\% gradient and stained with coomassie blue. Each lane was loaded with 10 $\mu \mathrm{g}$ of protein (Bradford, 1976). Major changes of protein bands indicated by arrows. Pum, Pummelo; Man, mandarin; Etr, etrog; TMV, tobacco leaves infected with TMV. Putative localization of tobacco PR-1-like protein, chitinase and b-1,3glucanase are indicated.

Additional serologically related isoforms of chitinase (Fig. 2B) and PR-1 (Fig. 2C) with higher molecular masses, appeared after $48 \mathrm{~h}$ of ethylene treatment. Further characterization of these isoforms was not completed at the present time.

A 3 and 10 fold increase in enzymatic activities of chitinase and B-1,3glucanase, respectively, was detected. The enzyme increases are in coordination with time of ethylene treatment. The maximum endogenous activity levels were 16.2 nkat ( $\mathrm{g}$ fresh weight) ${ }^{-1}$ for chitinase and 68.6 nkat (g fresh weight) ${ }^{-1}$ for $B-1,3$-glucanase.

Change in levels of $P R$ proteins following various stress conditionsAssessment of PRs accumulation, in response to various biotic or abiotic stress conditions, was performed by monitoring changes in the level of glucanase, chitinase and PR-1-like proteins, as reflected in their reaction with anti-PR-1, -P and -Q antibodies. 


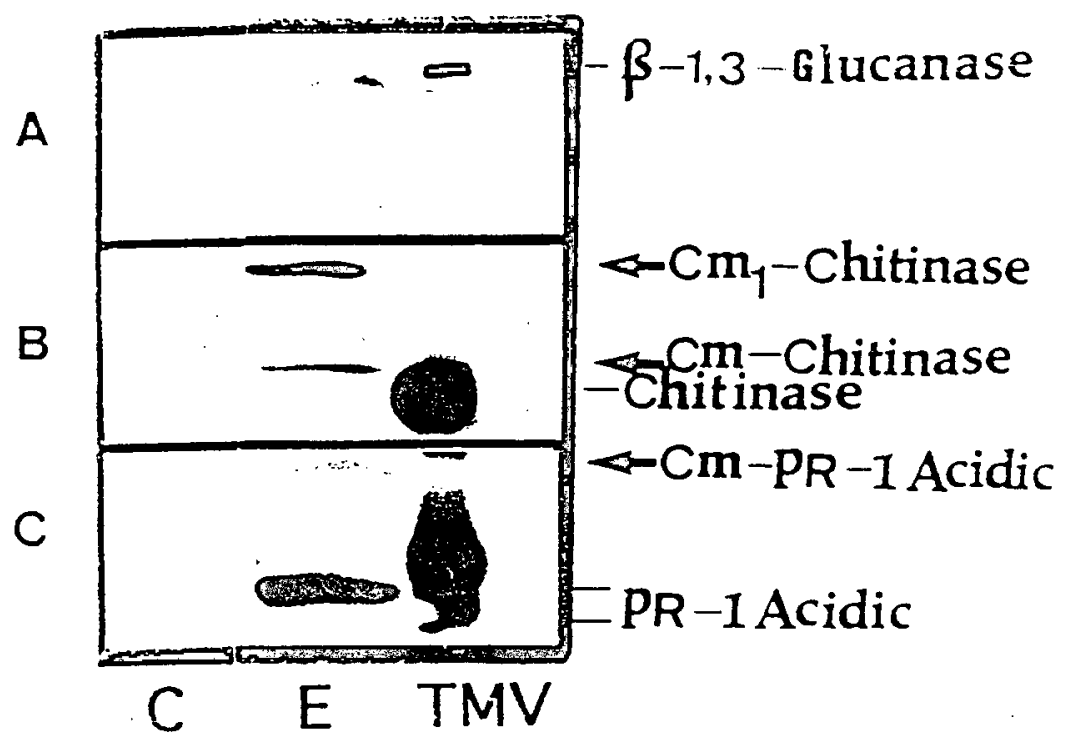

Fig. 2. Serological analysis of PR-like proteins in intercellular spaces of mandarin leaves following ethylene (E) treatment $\left(48 \mathrm{~h}, 15 \mu 1 \mathrm{~L}^{-1}\right)$. Immonoblot of denaturating PAGE was autoradiographed with antibodies from TMV infected tobacco (TMV) as the follows: A, anti-2,N,O (b-1,3-Glucanse); B, anti-PR-P,Q (Chitinase); C, anti-PR-1a,b,c (PR-1). Control (C) leaves were incubated in air. Arrows indicates novel mandarin isozymes of the corresponding PR.

Quantitative analysis of the autoradiographs showed (Fig. 3) that in $\mathrm{CEV}$ and $\mathrm{MS}$ infected trees chitinase-like-proteins levels were respectively 30 and 70 fold higher than in healthy ones. No significant increase in these PRs was detected after inducing flooding stress, or at the graft union of incompatible combinations (Fig. 3).

No significant changes in the level of glucanase-like proteins were noticed following CEV, INC or FL treatments while PR-1-like proteins increased only slightly following CEV and INC treatment and 1.2 fold following FL. PR-1 and glucanase were not determined in the extracts collected from the MS infected trees. TMV-infected tobacco leaves, and mandarin leaves pretreated with ethylene, were used as positive controls. In both of these treatments all three PRs increased considerably, as has been shown earlier (Figs. 1 and 2). 


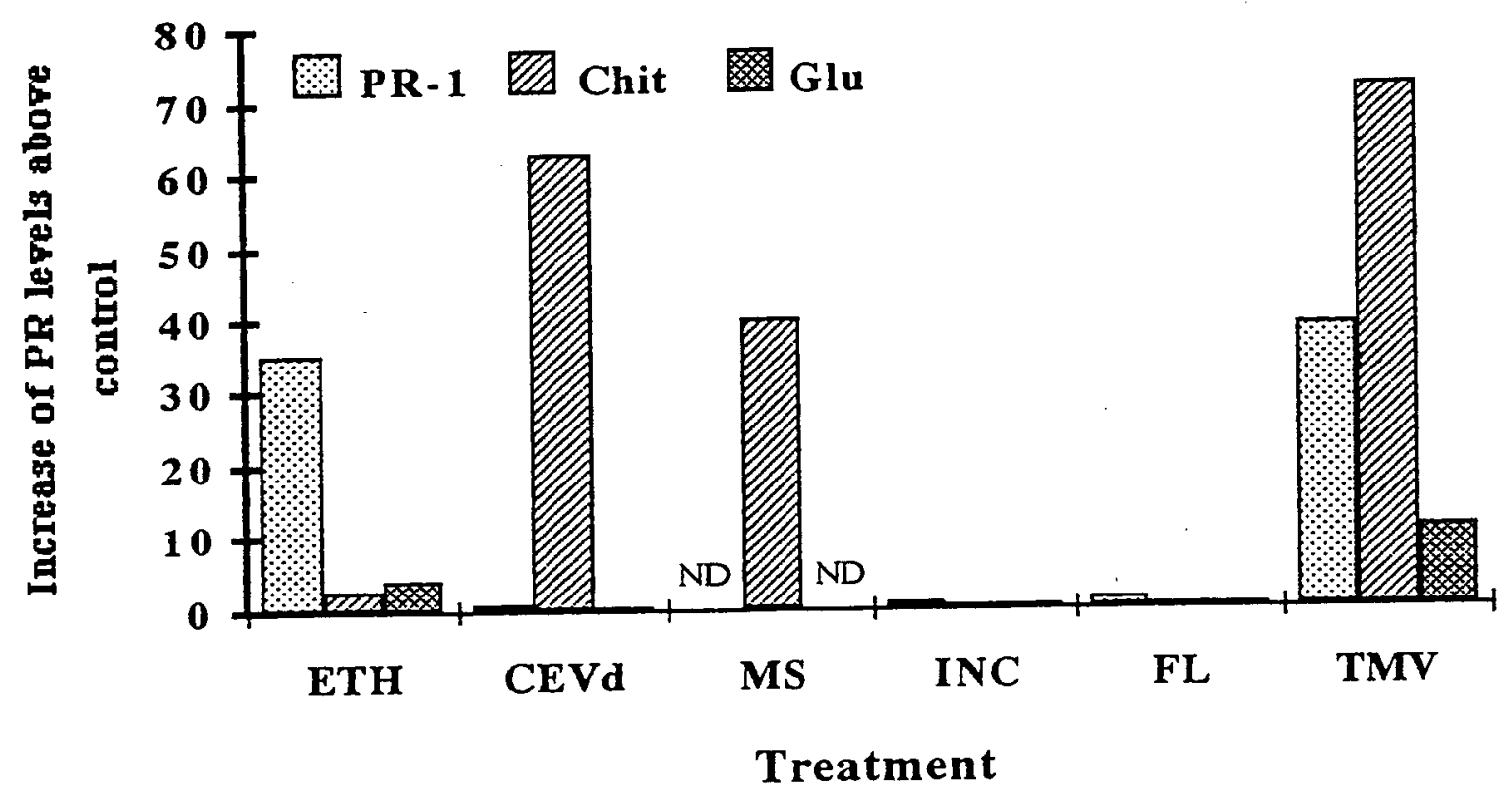

Fig. 3. Change in the level of Citrus PR-like proteins induced by ethylene or various stress conditions and excreted into the intercellular space. Relative levels were calculated from a computerized image analysis of signals on autoradiographs (as shown in Fig. 2). The amounts were calculated as follows: (treatment control)/control. PR-1, ( $)$ PR-1-like protein; Chit, (匂) Chitinase; Glu, ( b1,3-Glucanase. ETH, Ethylene; CEVd, Citrus Exocortis Viroid; MS, Mal Secco; FL, Flooding; TMV, Tobacco Mosaic virus; ND, Not Determined.

\section{Discussion}

Using antibodies raised against tobacco PR proteins (Lotan and Fluhr, 1990) we have identified a number of Citrus PR proteins that correspond to three major classes of PR proteins namely, chitinase, $\beta$ 1,3-glucanase and PR-1 (Fig 1). These proteins were induced by exogenous treatment with physiological levels of ethylene as has been shown before in various other plants like beans (Abeles et al. 1970; Boller et al., 1983; Mauch et al., 1989), tomato (Pegg, 1976) and tobacco (Eyal et al., 1992; Felix and Meins, 1987), but not in citrus.

The citrus PR proteins share some characteristics that were determined as typical to this group such as: low molecular weight, extractability with acidic buffers, inducibility by ethylene and possession 
of enzymatic activities known as chitinase and B-1,3-glucanase (Legrand et al., 1987; Linthorst, 1991; Van Loon, 1985).

In this paper we show three new PR-like proteins, CM-PR1-acidic, CM-chitinase and CM1-chitinase, that increase in mandarin leaves following ethylene treatment (Fig. 2). These proteins are serologically homologous to PRs in tobacco but differ in their molecular weight. No analysis was performed to further explore the nature of these proteins or to see whether they are glycosylated.

Like in sunflower (Jung et al., 1993) the level of PR-proteins in untreated citrus leaves depended on their growing conditions. Occasionally low levels of PRs were detected in controls plants, especially in leaves taken from trees grown in the field. This increase in the basal levels can be explained by possible infection by pathogens or abiotic stress conditions.

The maximum increase of chitinase-like proteins was detected in the extracellular space of plants infected with CEV and MS (Fig. 3). Since we used antibodies raised against intercellular wash of tobacco leaves infected with TMV it was most likely that they will better recognize PR isozymes of the same nature. It is possible that the affinity of these antibodies is lower for ethylene-induced chitinases than for the pathogenesis induce isozymes. Nevertheless, ethylene production increases during pathogen attack (Boller, 1988; Linthorst, 1991; Mauch et al., 1984), thus its effect should not be excluded unless ethylene inhibitors are applied (Felix and Meins, 1987, Mauch et al. 1984).

Infection with $\mathrm{CEV}$ has been shown to enhance PR-like proteins in tomato (Granell et al.1987; Vera and Conejero, 1988). In the present work we show, for the first time, the induction of these proteins in citrus infected with CEV (Fig. 3). The predominant increase, ca. 60 times over control, was in chitinase-like protein. This increase was in the same level of that observed in tobacco leaves infected with TMV (Fig. 3). Mal-secco infected trees responded, as expected from plant tissue under pathogenic stress (Legrand et al., 1987) with significant 40 fold increase in chitinase (Fig. 3). This chitinase can play a role in protecting the leaves from the fungi by hydrolyzing the fungal cell wall which contains chitin.

Although flooding causes stress in citrus roots ( $\mathrm{Vu}$ and Yelenosky, 1992), sometimes accompanied with increased ethylene levels, no increase in chitinase or b-1,3-glucanase was observed (Fig. 3). The 
same negative results were seen in the incompatible combinations, which showed severe damage in the graft union (Shklarman et al., 1992). However, in both treatments a significant, although very small increase in PR-1 protein was noted (Fig. 3). The role of this protein is not known but we established that in citrus this protein increases in response to various stress conditions.

Acknowledgments - We thank Prof. M. Bar-Joseph for the gift of the CEVd infected trees and Prof. R. Fluhr for the tobacco anti-PR protein antiserum.

\section{References}

Abeles, F.B. 1973., Ethylene in plant biology. Academic Press, New York.

Abeles, F.B., R.P. Bosshart, L.E. Forrence, W.H. Habig. 1970. Preparation and purification of glucanase and chitinase from bean leaves. Plant Physiol. 47:129-134.

Avrameas, S. and Guilbert, B., 1971. A method for quantitative determination of cellular immunoglobulins by enzyme-labeled antibodies. Eur. J. Immunol. 1:394-396.

Boller, T. 1988., Ethylene and the regulation of antifungal hydrolases in plants. Oxford Sur. Pl. Mol. Cell Biol. 5:145-174.

Boller, T., Gehri, A., Mauch, F. and Vogeli, U., 1983. Chitinase in bean leaves: Induction by ethylene, purification, properties, and possible function. Planta 157:22-31.

Boller, T. and Metraux, J.P., 1988. Extracellular localization of chitinase in cucumber. Physiol. Mol. Plant Pathol. 33:11-16.

Boller, T. and Vogeli, U., 1984. Vacuolar localization of ethyleneinduced chitinase in bean leaves. Plant Physiol. 74:442-444.

Bradford, M.M. 1976., A rapid and sensitive method for the quantification of microgram quantities of protein utilizing the principle of protein-dye binding. Anal. Biochem. 72:248-254.

Dahan, Y. and Sagee, O., 1992. Effect of ethylene on the induction of B1,3-glucanase and chitinase in citrus leaves. Proc. Int. Soc.

Citriculture. Acireale, Italy. In Press.

Eyal, Y., Sagee, O. and Fluhr, R., 1992. Dark-induced accumulation of basic pathogenesis-related (PR-1) transcript and light requirement for its induction by ethylene. Plant Mol. Biol. 19:589-599. 
Felix, G. and Meins, F. Jr., 1987. Ethylene regulation of B-1,3glucanase in tobacco. Planta 171:386-392.

Granell, A., Belles, J.M. and Conejero, V., 1987. Induction of pathogenesis-related proteins in tomato by citrus exocortis viroid, silver ion and ethephonc. Phisiol. Mol. Plant Pathol. 31:83-90.

Jung, J.L., Fritig, B. and Hahne, G., 1993. Sunflower (Helianthus annuus L.) pathogenesis-related proteins. Plant Physiol. 101:873-880.

Keefe, D., Hinz, U. and Meins, F. Jr., 1990. The effect of ethylene on the cell-type-specific and intercellular localization of B-1,3-glucanase and chitinase in tobacco leaves. Planta 182:43-51.

Klotz, L.J. 1978., Fungal, bacterial and nonparasitic diseases and injuries originating in the seedbed, nursery and orchard. In: W. Reuther, E.C. Calavan, G.E. Carman. eds. The Citrus Industry. Vol. IV. pp.1-66.

Laemmli, U.K., 1970. Cleavage of structural proteins during the assembly of the head bacteriophage T4. Nature 227:680-685.

Legrand, M., Kauffmann, S., Geoffery, P. and Fritig, B., 1987. Biological function of pathogenesis-related proteins: Four tobacco pathogenesis-related proteins are chitinases. Proc. Natl. Acad. Sci.USA 84:6750-6754.

Linthorst, H. J. M., 1991. Pathogenesis-related proteins of plants. Crit. Rev. Plant Sci.10:123-150.

Lotan, T., Ori, N. and Fluhr, R., 1989. Pathogenesis-Related proteins are developmentally regulated in tobacco flowers. Plant Cell. 1:881887.

Lotan, T. and Fluhr, R., 1990. Function and regulated accumulation of plant pathogenesis-related proteins. Symbiosis 8:33-46.

Mauch, F. and Staehelin, L.A., 1989. Functional implications of the subcellular localization of ethylene-induced chitinase and B-1,3glucanase in bean leaves. Plant Cell 1:447-457.

Mauch, F., Hadwiger, L.E. and Boller, T., 1984. Ethylene: symptom, not signal for the induction of chitinase and B-1,3-glucanase in pea pods by pathogens and elicitors. Plant Physiol. 76:607-611.

Pegg, G.F., 1976. The response of ethylene-treated tomato plants to infection by Verticillium albo-atrum. Physiol. Plant. Pathol. 9:215226. 
Shklarman, Y., Safran, H. and Sagee, O., 1992. Microscopic study of graft union characteristics wand water translocation in young citrus budlings. Proc. Int. Soc. Citriculture. Acireale, Italy. In Press.

Swingle, W.T., 1967. The botany of citrus and its wild relatives. In: W. Reuther, ed. The Citrus Industry. Vol. 1. pp.190-430

Towbin, H.,Staehlin, T. and Gordon, J., 1979. Electrophoretic transfer of proteins from polyacrylamide gels to nitrocellulose sheets: procedure and some applications. Proc. Natl. Acad. Sci. USA 76: 4340-4354.

Van Loon, L.C. 1985. Pathogenesis-related proteins. Plant Mol. Biol. 4:111-116.

Vera, P. and Conejero, V., 1988. Pathogenesis-related proteins of tomato. Plant Physiol. 87:58-63.

Vogeli, U., Meins, F. Jr. and Boller, T., 1988. Co-ordinated regulation of chitinase and $\beta-1,3$-glucanase in bean leaves. Planta 174:364-372.

Vu, J. C. V. and Yelenosky, G., 1992. Photosynthetic responses of rough lemon and sour orange to soil flooding, chilling, and shortterm temperature Fluctuations during growth. Environ. Exp. Bot. 32:471-477.

Wallace, J.M., 1978. Virus and viruslike diseases. In: W. Reuther, E.C. Calavan, G.E. Carman. eds. The Citrus Industry. Vol. IV. pp.67-184. 


\section{Microscopic Study of Graft Union Characteristics and Water Translocation in Young Citrus Budlings}

\section{Introduction}

Various causes such as edaphic and climatic factors and the tristeza virus, constitute a constant need for new citrus rootstocks (Wutscher, 1979). Introducing new rootstocks require a long and expensive process of evaluation and testing. Therefore, their is a great need for rapid evaluation methodes that will enable the elimination of problematic stionic combinations before entering the stage of field experiments.

The phenomenon of incompatibility between rootstock and scion is well recognized in many fruit trees and is the result of the joining together of two plant tissues of genetic difference (Castle, 1987). In citrus, certain stock-scion (stion) combinations, in particularly those on rootstocks from the trifoliata family (Poncirus trifoliata [L.] Raf.) might develop late bud union crease (Bitters et al., 1977; Rouse and Wutscher, 1985). Trees of 'Shamouti' orange (C. sinensis [L.] osbeck) grafted on Swingle citrumelo (C. paradisi $x$. trifoliata) scems to be incompatible and there are cases of decline after 8 years of seemingly proper growth (Ashkenazi, 1988).

Physiological and/or microanatomical differences between the two tree partners may cause the development of bud union disorders often called 'incompatibility'. Very few attempts were made to study, on the anatomical level, the early stages of bud union development in citrus (Mendel, 1936).

The following work was initiated to find out differences at the graft union tissues during the healing process of various 'compatible' and 'incompatible' stionic combinations. It is also aimed to develop criterions for screening out, as early as possible, combinations which might develop late bud union crease.

The parameters studied were: $A$, nature and time sequence of anatomical changes in the graft-union zone. B, reorganization of the water transport elements between the rootstock and the scion. $C$, changes in starch accumulation at the bud union. $D$, callose build up. $E$, localization of different phenols such as catechins and tannins above and below the bud union. 


\section{Materials and Methods}

Seedlings, 12-16 months old, were grown in screenhouse under standard conditions. Five graft combinations were employed. Three of 'incompatible' combinations: calamondin (C. reticulata Aus.? x Fortunella sp.?) grafted on troyer citrange (Poncirus trifoliata [L.] Raf. $x \quad C$. sinensis), kumquat (Fortunella Sp.) grafted on troyer and calamondin grafted on sour orange ( $C$. aurantium). Two of 'compatible' combinations: shamouti ( $C$. sinensis) grafted on sour orange and star ruby grapefruit $(C$. paradisi) grafted on sour orange.

Grafting was by chip-budding, and when bud-break was observed the rootstocks were cut about $1-2 \mathrm{~cm}$ above the bud. Samples of the graft area were collected starting from 2 months after budding and up to 15 months thereafter. Fresh sections of all the combinations were cut on a freezing microtome and stained by the standard safranin-fast green method for the study of the tissues at the bud union. The development of the graft union of kumquat on troyer was also followed up with time. For studying water transport the seedlings were cut few $\mathrm{cm}$ below the graft and dipped in distilled water containing $0.5 \%$ safranin until the red color reached the leaves. Thereafter, the graft unions were cut as above and then stained with fast green only.

Starch, as a storage product, was demonstrated using the Iodinepotassium-iodide staining. For evaluating callose build up the samples were stained with anilin-blue and observed in microscope under fluorescent light. Tannins, appearing in necrotic cells were detected by the nitroso reaction. Catechins were stained by DMACA (Feucht et al., 1983).

\section{Results and Discussion}

In citrus, during the development of graft, differentiation of the cambium occurs after 10 days in the callus of the bark flaps and after 15 days in callus of the bud shield. The occurrence of the first xylem tracheids is 5 days later for each tissue, respectively. Lignification is completed in both tissues as early as 30 days and as late as 45 days (Mendel, 1936). Therefore, in order to follow the early events in the development of graft union, our first observations were made 2 months after grafting.

In kumquat budded on troyer ('incompatible' combination), bark and wood of the two partners are already connected 2 months after grafting (Fig. 1). 
At this time, necrotic cell layer was mostly observed where cells from both partners met. This is probably wound induced necrosis. Curved combined xylem elements were present in the stock and in the scion. Direct contact between the two partners by callus growth was either complete or interrupted by air gaps. Vascular continuity was established between the scion and the rootstock during the first two months after grafting as seen by the safranin staining of the cell walls of the conducting vessels and adjacent cells (Fig. 1). These results are consistent with the suggestion that initial cohesion of graft partners does not involve mutual recognition (Moore and Walker, 1981).
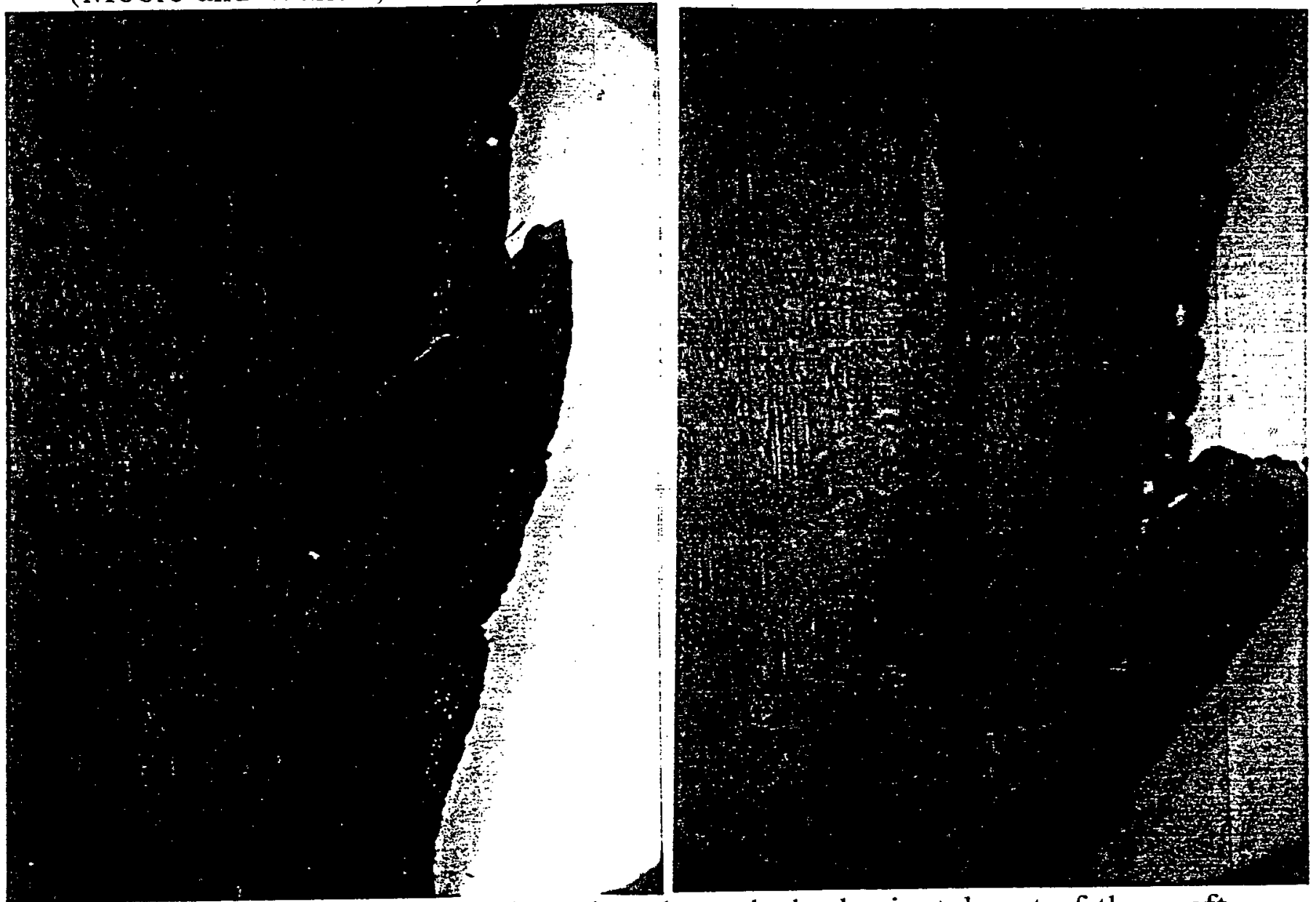

Fig. 1. (left) Longitudinal section through the basipatal part of the graft union; 2 months after budding of kumquat $(\mathrm{k})$ on Troyer $(\mathrm{t})$ seedlings. Note the callus (c) tissue fitting almost entirely to both partners. Curved combined xylem elements of rootstock (rs) and scion (xs), and necrotic (n) layer are seen. $\mathrm{X} 40$.

Fig. 2. (right) Longitudinal section through the basipetal part of the graft union; 10 months after budding of kumquat $(k)$ on Troyer $(t)$ is well developed at the basipetal end. Necrotic layer (n). Bark of scion (bs) and rootstock (br) is not connected. X40. 
Ten months after grafting bark and xylem were not attached, excess callus accompanied with necrosis was formed and the vascular system was swirled (Fig. 2). Note that graft partners are not yet united at the graft union suture although callus (c) tissue. In most plants of kumkuat budded on troyer bud union was less successful then in plants of star ruby budded on the same rootstock (data not presented).

The development of symptoms that can be attributed to 'incompatibility' occurred 10 months after grafting and could not be observed at 2 months after grafting.
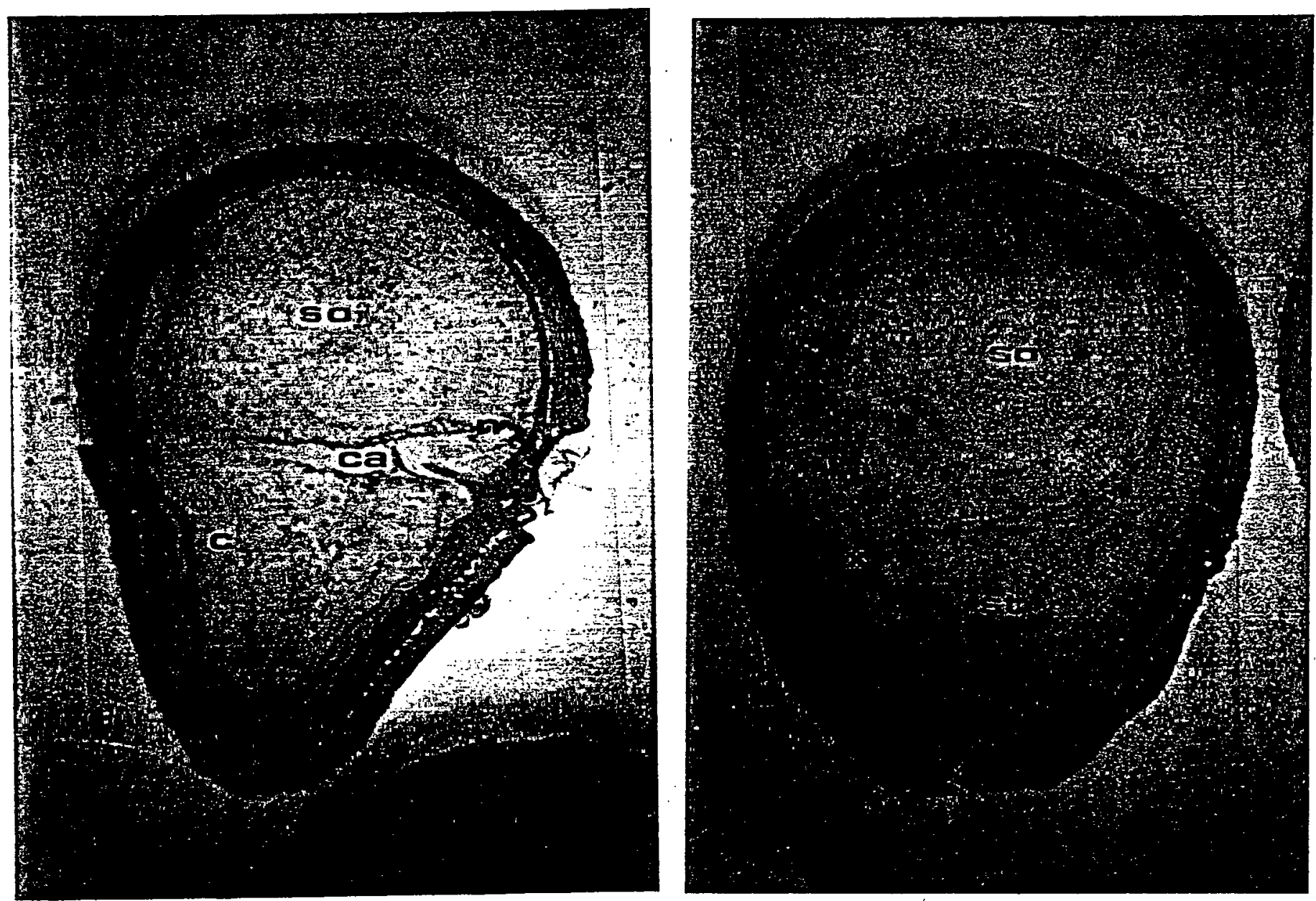

Fig. 3. (left) Transverse section through the graft union; 10 months after budding of calamondin (c) on sour orange (so). Note the blocks of callus (ca) growing into gaps from the two edges of the bud union. Water transporting elements (wt) are very few and are spread in the rootstock stub. Necrotic layer (n). X30.

Fig. 4. (right) Transverse section of the graft union; 10 months after budding of Star Ruby (sr) grapefruit on sour orange (so). Note the successful union of the xylem (x) tissues between the stock and the scion. The strong staining of the water transporting elements (wt) indicate increased water translocation. X25. 
In plants of star ruby grafted on sour orange there was a clear increase of the xylem elements resulting in increased water transport (Fig. 4). As the plants grew the development of the water transporting elements continued, avoiding the necrotic areas.

For better understanding of the vascular system and to determine the allocation of water transport elements transverse sections were performed. In calamondin budded on sour orange, a combination that is considered to be of bad compatibility, clear necrotic layers were present (Fig. 3).

The progressive development of tissues within the graft union was uneven and filled by proliferating ray tissue which did not lignify normally. On the other hand, in star ruby budded on sour orange, a successful combination, coherent union with almost no necrosis was observed (Fig. 4).
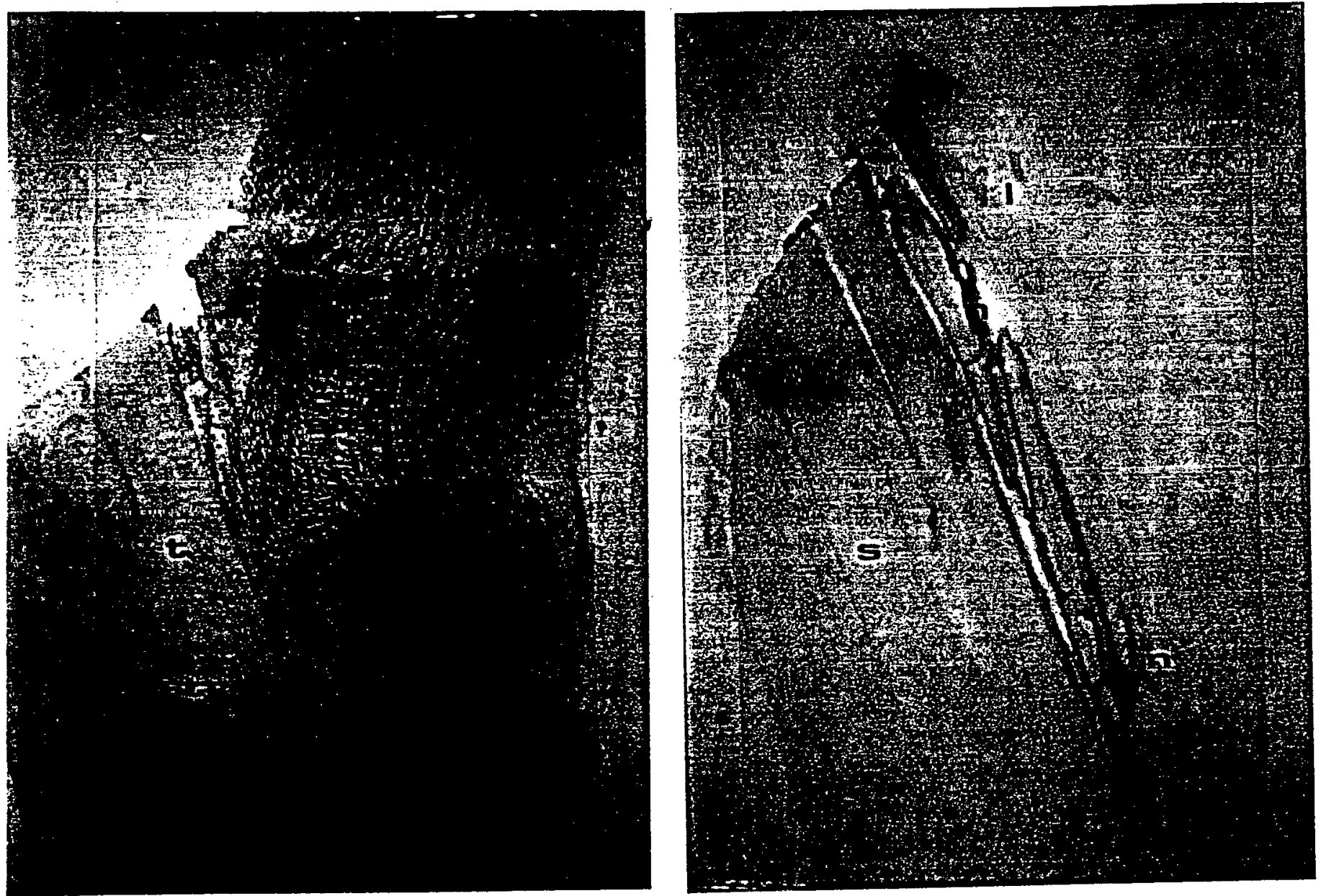

Fig. 5. (left) Longitudinal section of the graft union; 15 months after budding of calamondin (c) on Troyer (t). Starch accumulation in the scion (sts) and in the rootstock (str) is presented. X35.

Fig. 6. (right) Longitudinal section of the graft union; 10 months after budding of lemon (l) on Severinia (s). Note the accumulation of tannins $(\mathrm{tn})$ along the union area and the necrotic layer (n). X45. 
The xylem build up was more excessive and better developed. The strong staining of the water transporting elements indicate increased water transport into the young xylem of the star ruby scion.

Starch build up was often attributed to problems in the bud union (Simons and Chu, 1984). In shamouti budded on sour orange (a successful combination) starch was present in both the scion and rootstock (data not shown), while in calamondin budded on troyer starch was mainly in the xylem of the scion (Fig. 5).

Although we can not, yet, draw any conclusions regarding the possible correlation between starch build up at the graft area and compatibility of different citrus combinations it seems that the starch accumulation was in the scion above the graft union of the 'incompatible' combinations, as was suggested before (Mendel and Cohen, 1967). It should be further investigated during other seasons of the year.

Callose formation at the graft zone was very variable and was more dependent on the plant age than on the stionic combination. The fluorescence could be detected above and bellow the graft area but the strongest signal was in the tissues adjacent to the wound from the grafting. It seems therefore that at this point the level of callose can not be used as a reliable indicator for 'incompatibility'.

Phenols are known to accumulate as the result of wounding and to be involved with the initiation of necrotic cells. They are mentioned as a good parameter for recognizing incompatibility in cherry and other trees (Feucht et al., 1983). Accumulation of tannins along the union area was recognized in all grafts and a typical tannin build up is presented in the example of kumquat budded on troyer (Fig. 6).

The presence of catechin as an oxidative agent during cell necrosis was determined in calamondin grafted on troyer (Fig. 7). There were few differences in the qualitative pattern of the tannin and catechin accumulation in the graft union zone between the different stock-scion combinations, calamondin grafted on sour orange and troyer showed the highest catechin build up.

It is possible that in Citrus, like in Sedum (Moore, 1984), adhesion of the scion to the rootstock is a passive event occurring at an early stage during wound-healing in both compatible and incompatible grafts, so that it usually does not require cellular contact or mutual cell recognition .

Our studies show that water transport can be recognized in certain areas of the xylem as early as two months after grafting. It is clear that this is one of the most vital processes that enable surviving of the sprouting scion. 


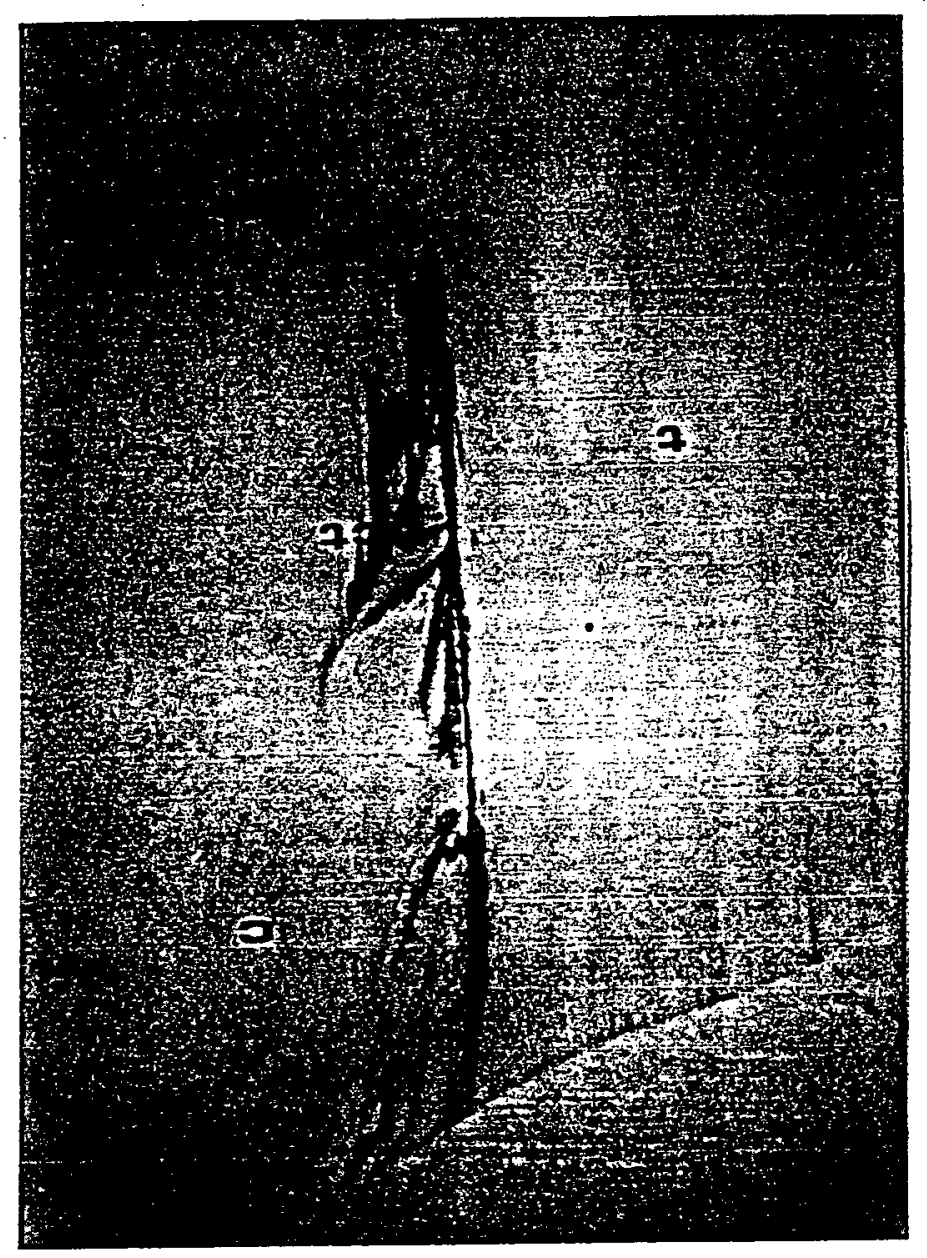

Fig. 7. Longitudinal section of the graft union; 15 months after budding of calamondin (c) on Troyer ( $t$ ). Note catechin (ct) build up in the cells of the necrotic layer $(n) . \times 35$.

Nevertheless, this parameter can not be used as a marker for 'incompatibility' during the first months after grafting since it was observed in all combinations. The development of the 'incompatible' phenomenon is probably at a later stage that follows the first stage of cohesion.

Proper development of the graft-union is on of the major criterions that should be considered when a new stock-scion combination is evaluated. The results obtained so far enable several basic characterization of the graft zone. After establishing the parameters that distinguish 'compatible' from 'incompatible' combinations we expect to use them for screening of new stionic combinations. 


\section{Literature Cited}

Ashkenazi, S. 1988. Incompatibility of some stock-scion citrus combinations in Israel. Proc. Sixth Int. Citrus Cong. 1:57-60.

Bitters, W.P., D.A. Cole and C.D. McCarty. 1977. Citrus relatives are not irrelevant as dwarfing stocks or interstock for citrus. Proc. Int. Soc. Citriculture. 2:561-567.

Castle, W.S. 1987. Citrus rootstocks. p. 361-399. In: R.C. Rom and R.F. Carlson (eds.), Rootstocks for fruit crops. J. Wiley \& Sons, N.Y.

Feucht, W., P.P.S. Schmid and E. Christ. 1983. Compatibility in Prunus avium/Prunus ceraus grafts during the initial phase. I. The structure of the phloem inclusive sieve tubes. Gartenbauwissenschaft 48:45-50.

Mendel, K. 1936. The anatomy and histology of the bud-union in Citrus. Pal. J. Bot. 1:13-46.

Mendel, K. and A. Cohen. 1967. Starch level in the trunk as a measure of compatibility between stock and scion in citrus. J. Hort. Sci. 42:231241.

Moore, R. 1984. The role of direct cellular contact in the formation of compatible autografts in Sedum telephoides. Ann. Bot. 54:127-133.

Moore, R. and D.B. Walker. 1981. Studies of vegetative compatibilityincompatibility in higher plants. I. A structural study of a compatible autograft in Sedum telephoides (Crassulaceae). Amer. J. Bot. 68:820830.

Rouse, R.E. and H.K. Wutscher. 1985. Heavy soil and bud union crease with some grapefruit clones limit use of Swingle Citrumelo rootstock. Hortscience 20:259-261.

Simons, R.K. and M. Chu. 1984. Tissue development within the graft union as related to dwarfing in apple. Acta Hort. 146:203-210.

Wutscher, H.K. 1979. Citrus rootstocks. Hort. Rev. 1:237-269. 